Araştırma Makalesi

\title{
"Tık" ve "Etik" Arasında Sıkışan Gazetecilik: İnternet Gazeteciliğinin Ortaya Çıkardığı Yeni Etik Sorunlar Ve Gazetecilerin Konuya Bakış Açısı Üzerine Bir Araştırma
}

\author{
Elif Korap Özel (Doç. Dr.) \\ İzmir Kâtip Çelebi Üniversitesi Sosyal ve Beşeri Bilimler Fakültesi \\ elifkorap@hotmail.com \\ Orcid: 0000-0002-1332-5715 \\ Şadiye Deniz (Doç. Dr.) \\ Ege Üniversitesi İletişim Fakültesi \\ aysadiye@hotmail.com \\ Orcid: 0000-0002-7929-4077
}

Başvuru Tarihi: 23.05.2018

Yayına Kabul Tarihi: 16.11.2018

Yayınlanma Tarihi: 21.01.2019

\section{Öz}

Bu çalışma, dijitalleşmeyle birlikte her geçen gün dönüşmeye devam eden gazetecilik pratikleri ve mesleğin aldığı yeni biçim doğrultusunda beliren yeni etik sorunları ortaya koymayı amaçlamaktadır. Dijitalleșmenin etkisinin kapsamını ve şiddetini tespit edebilmek için gazetecilikte dijitalleşme pratiğinin ilk elden deneyimleyicisi olan internet editörlerinin görüşlerine başvurulmuştur. Bu kapsamda 15-20 Ocak 2018 tarihlerinde İstanbul'da Hürriyet, Milliyet, Sabah gazetelerinde görev yapmakta olan internet editörleri ile görüşülmüştür. Çalışmada veri toplama aracı olarak Patton'un "görüşme formu tekniği"ne başvurulmuş, elde edilen verilere içerik analizi uygulanmıştır. Çalışmanın sonuçlarına göre gazeteciler, dijitalleşmenin gazetecilikte haber üretim sürecine olumlu ve olumsuz etkileri olduğunu düşünmektedir. Gazeteciler, haberler dolayımıyla hem habercilik hem de okur açısından geleneksel basında daha önce karşılaşılmayan yeni etik sorunların ortaya çıktığını da düşünmektedir. Bunlar arasında yeni gazetecilikte artık editörün "masabaşı muhabir" rolünü üstlenmesi, "tık odaklı bir gazetecilik pratiğinin yaygınlaşması", "haber kaynağı ve habere erişimin şartlarının değişmesi", "hataların ve gerçekdışı haberlerin hızla yayılması", "hız tuzağı” ve "sanal galeriler” öne çıkmaktadır.

Anahtar Kelimeler: İnternet Gazeteciliği, Tık Tuzağı, Haber, Etik. 
Research Article

\title{
Journalism Squeezed Between "Click" and Ethics: An Investigation of the New Ethical Problems Raised by Internet Journalism and Journalists' Views On
}

\author{
Elif Korap Özel (Doç. Dr.) \\ İzmr Katip Çelebi University \\ Faculty of Humanities and Social Sciences \\ elifkorap@hotmail.com \\ Orcid: 0000-0002-1332-5715 \\ Şadiye Deniz (Doç. Dr.) \\ Ege University Faculty of Communication \\ aysadiye@hotmail.com \\ Orcid: 0000-0002-7929-4077
}

Date Received: 23.05.2018

Date Accepted: 16.11.2018

Date Published: 21.01.2019

\begin{abstract}
The aim of this study was to investigate the rapid changes in journalistic practice occurring along with digitalization and the new ethical problems emerging as a result of this new shape of the profession. In order to assess the scope and intensity of the effect of digitalization, the views were sought of the internet editors themselves, who have the primary direct experience of the practice of digitalization. Therefore, the internet editors of Hürriyet, Milliyet and Sabah newspapers were interviewed in İstanbul between 15 and 20 January 2018. Patton's interview form technique was used as a data gathering instrument, and content analysis was applied to the data gathered. According to the results of the study, journalists thought that digitalization had both positive and negative effects on the news production process in journalism. They also thought that new, ethical problems in the transmission of news, previously unencountered in the traditional press, had arisen both for journalism and for readers. Foremost among these were the editor taking the role of a desk-based reporter in the new journalism, the spread of click-focused journalistic practice, news sources and changes in the conditions of accessing news, the rapid spread of mistakes and fake news, the click trap, and virtual galleries.
\end{abstract}

Keywords: Digital Journalism, Clic-bait, News, Ethic. 


\section{Giriş}

Maruz kaldığımız, gönüllüsü olduğumuz, nihayetinde gündelik hayatımızın ayrılmaz bir parçası haline gelen yeni medyanın, en çok müdahil olduğu ve değiştirdiği alanlardan biri gazetecilik olmuştur. Yeni medya araçlarının kitleler tarafından yaygın kullanımı, gazetelerin daha çok okura ulaşabilmesi için yeni bir mecra sağlamış, böylece gazeteler aynı zamanda dijital platformlara da taşınmıș, hatta sadece dijital yayıncılık yapan iletişim araçları da ortaya çıkmıştır.

Dijitalleşen gazetecilik, geleneksel gazeteciliğin hali hazırdaki etik sorunları yanında, alışılmadık yeni etik ihlalleri de beraberinde getirmiştir. Gazeteciliğin, ideolojiden, kurumsal yapıdan, medya sahipliğinden kaynaklanan alışılagelmiş etik sorunları olarak; haber intihalleri, bazı kişi ya da grupların haberlerde eksik/yanlış temsilleri, özel hayata ve kişilik haklarına müdahale, haber kaynağıyla ilgili etik ihlaller, haber - reklam ayrımının yapılamaması gibi konular dijital gazetelerde de ortaya çıkmaktadır. Ancak geleneksel medya etiği yaklaşımları, zaman içerisinde bu sorunlara çözüm olabilecek gazetecilik meslek ilkelerini de üretmeyi başarmıştır ve bunların kısmen de olsa başarılı olduğunu söylemek mümkündür. Dijitalleşmeyle birlikte karşı karşıya kalınan durum ise, hem medya profesyonelleri, hem okurlar için yenidir. Dijital ortamın etkileşimlilik, hipermetinsellik, multimedya gibi doğasından kaynaklanan özellikleri, haber üretiminde, haberin yayımında, okurun rolünde geleneksel basılı gazetecilikten çok farklı, deneyimledikçe anlayabileceğimiz, bu nedenle hala öğrenmeye devam ettiğimiz durumlar/sonuçlar ortaya çıkarmıştır. Çalışmanın ilerleyen bölümlerinde ayrıntılarıyla açıklanan bu etik ihlal durumları, dijital gazeteciliğin nevi şahsına münhasır özellikleri olan "hız" ve "okur odaklılık" faktörlerinden kaynaklanmaktadır. Gazetecilik mesleği dijitalleşme ile birlikte tıklanma hedefleri, sayfa görüntüleme sayısı, tık tuzağı, yanıltıcı başlık, banner, advertorial, arama motoru optimizasyonu gibi yeni kavramlarla ve etik sorunlarla tanışmıştır. Tüm bunların okur/alımlayıcı açısından doğurduğu sonuç ise, Ionna Kuçuradi'nin (1999) dediği gibi dünyadaki olup bitenler, yani haber hakkında kendi fikrimizi oluşturma deneyiminden mahrum kalmamızdır.

$\mathrm{Bu}$ çalışma, dijital gazetecilikte karşılaşılan etik sorunları, dijital habercilik profesyonellerinin gözüyle ortaya koymayı amaçlamaktadır. Çalışmada kavramsal ardalan olarak etik, medya etiği, yeni medya etiği konularına yer verilmiştir. Araştırma kısmında ise, 15-20 Ocak 2018 tarihleri arasında İstanbul'da Hürriyet, Milliyet, Sabah gazetelerinde görev yapmakta olan 15 internet editörü ile görüșülmüştür. Çalıșmada veri toplama aracı olarak Patton'un "görüşme formu tekniği"ne başvurulmuş, elde edilen verilere içerik analizi uygulanmıştır.

Dijital dünyada gelişmeler büyük bir hızla ve kesintisiz olarak yaşanmaya devam etmekte ve gazetecilik de sürekli olarak bu gelişmelere ayak uydurmaktadır. $\mathrm{Bu}$ doğrultuda dijitalleşmenin gazeteciliğe etkisi ve internet gazeteciliğindeki etik sorunlar tek bir kerede ele alınabilecek bir konu değildir; yeni uygulamalar, yeni gazetecilik biçimlerini ve elbette gazetecilikte yeni etik sorunları ortaya çıkardıkça bu konu üzerinde tartışılması gereken bir başlık olarak durmaya devam edecektir.

\section{İnternet Gazeteciliğinde Karşılaşılan Etik Sorunlara Dair Literatür}

İnternet gazeteciliği, okurun haber üretim sürecine katılımına olanak sağlayan, okurun video, yazı, ses, görüntü gibi haberciliğin bütün formatlarını bir arada bulabildiği, arşive başvurabildiği, gazetecilik açısından ise maliyeti düşüren, zaman 
tasarrufu sağlayan, veri ve robot gazetecilik gibi masabaşı habercilik olanaklarına sahip, gazeteciliğe dair tüm süreçlerin dijital olarak gerçekleştirildiği habercilik türünü ifade etmektedir. Literatür incelendiğinde internet gazetelerinin farklı kategoriler altında ele alındığı görülmektedir. Mark Deuze dijital ortamda cereyan eden habercilik türlerinin hepsine online gazetecilik adını verir ve bunları ana akım haber siteleri, endeks/kategori siteleri, eleştiri/yorum siteleri ve paylaşım/ tartışma siteleri olmak üzere dört kategoriye ayırır (Deuze, 2003, 205). Bu türlerden en yaygın olanı, bu çalışmanın örnekleminde de ele alındığı gibi geleneksel medya kuruluşlarının web sitelerini oluşturan ana akım haber siteleridir.

Etkileşimlilik, hipermetinsellik ve multimedya özelliklerine sahip internet gazeteleri, haber üretim süreci, reel bir ölçümün mümkün olması, okurun haber odasının içinde yer alması gibi birçok özelliği bakımından geleneksel medyanın haber değeri, habere etki eden unsurlar gibi alışılagelmiş kalıplarını dönüştürmüştür. Bu durum, gazeteciliğin basılı formlarında karşılaşılmayan yeni birtakım etik sorunları da beraberinde getirmiștir. Medyanın hâlihazırda var olan etik ihlalleri internet gazeteciliğinde de sürmektedir ancak bunlara ek olarak okuru aktif kılan teknolojilerle birlikte başkaca yeni etik sorunlar da ortaya çıkmıştır. Yeni medya gazeteciliğinin yarattığı etik sorunların, geleneksel gazetecilikten daha etkili ve yaygın olduğunu söylemek mümkündür. Zira Mutlu Binark'ın da belirttiği gibi yeni medya araçları artık "bedenin bir uzantısı haline dönüşmüş" (Binark, https://yenimedya.wordpress.com/calismalar/), gündelik yaşantımızın ayrılmaz bir parçası, vücudumuzun bir uzvu gibi olmuştur. Dolayısıyla geleneksel medyada bir haberin yayılımı ancak sınırlı bir okuyucu kitlesi kadarken, yeni medya haberciliğinde herkesin her an ulaşabilir olması sebebiyle daha fazla sayıda insanın etik olarak sorunlu haberlerle karşılaştığını söylememiz mümkündür. $\mathrm{Bu}$ nedenle yeni medya gazeteciliğindeki etik sorunları, ayrı bir kategori olarak yeniden tartışma ihtiyacı doğmuştur.

$\mathrm{Bu}$ çalışmanın temel konusu internet gazeteciliğinde meydana gelen değişimler nedeniyle ortaya çıkan etik sorunlardır. Bu nedenle çok kapsamlı bir alanı olan etik kavramından ziyade, çalışmanın sınırlılıkları da göz önünde bulundurularak, internet gazeteciliği uygulamalarında ortaya çıkan sorunlar ve çözüm önerilerine odaklanılmıştır. Ancak ardalan bilgisi oluşturması bakımından kısaca etik ve medya etiği konularına değinmenin yararlı olacağı düşünülmektedir. Bu kavramlar açlklandıktan sonra, yeni medya gazeteciliğinde karşılaşılan etik sorunlara dair literatür ortaya konulacaktır.

Çoğu zaman ahlak kavramı ile eşanlamlı olarak kullanılan etik, "erdemin felsefi incelenmesidir. Etik araştırma alanına verilen isimdir; ahlaklılık veya erdem ise araştırmanın nesnesinin/konusunun ismidir. Erdem belli bir yer ve zamanda belli bir grupta, cemaatte veya toplumda kabul edilebilir davranış kodlarıdır." (Erdoğan, 2006, 5) Bu bağlamda etiğin erdemin / ahlakın düşünsel düzeyini ifade ettiğini, ahlak ya da erdem kavramlarının ise toplumsal olarak uygun olan davranışları sergilemek olduğunu söyleyebiliriz. Meslek etiği dediğimiz zaman ise, o işi icra edenlerin benimsediği ve uyguladığı ilkelerden/kodlardan söz edilmektedir. Bu kodlar, bireysel, kurumsal, sektörel veya toplumsal olabilir. Medya etiği; habercilik işini yapanların, bu mesleği icra ettiği her aşamada, tanımlanmış kurumsal, bireysel ve toplumsal ilkeler/kodlar ekseninde davranış ortaya koymasıdır. 
Gazetecilerin her zaman kendilerinden beklenen standartlarda hareket etmemesinin, etiğin gazetecilikle ilgili olmadığı anlamına gelmeyeceğini söyleyen Andrew Belsey ve Ruth Chadwick, gazetecilik ve etik konusunda şunları söylemektedir: "Gazetecilik uygulamalarının büyük bir kısmı özgürlük, yansızlık, doğruluk, dürüstlük ve mahremiyet gibi kaçınılmaz olarak etikle ilgili olan kavramlarla ilintilidir. Etik gazetecilikten ayrılamaz ve etikle ilgili tartışmalar, uygulamaları ve sorunlarıyla birlikte gazeteciliği anlamanın bir parçası olmalıdır"(Belsey \& Chadwick, 1998, 10). Kuçuradi ise, gazetecilikteki etik sorunların gazeteciliğin amaçları ile ilgili olduğunu söylemektedir. Gazeteciliğin amacl, etrafımızda ve dünyada neler olduğunu bilme imkânı sağlama ve olan bitenler hakkında kendi düşüncemizi şekillendirmek gibi temel kişisel hakkımızın deneyimini yaşamaya katkı sağlamaktır. Kuçuradi'ye göre; gazetecilikteki etik sorunları, çoğu insanın düşündüğü gibi, manipülasyon, fotomontaj başlatmamıștır, etik sorunlar, diğer şeyler arasında kendi aracını, ortamını, gazetecilikle ilgili olmayan amaçlar için kullanan gazeteciler tarafından yaratılmıştır (Kuçuradi, 1999, 12-13).

Medya etiğine ilişkin başka bir çalışma Huub Evers'e aittir. Evers'e göre; gazetecilik etiği, gazetecinin karşılaştığı farklı durumlarda kaldığı ikilemlerde yol gösterici bir işleve sahiptir. Ona göre, gazete editörlerinin ve çalışanlarının meslek etiğinden söz ederken dört farklı düzey kastedilmektedir; kişisel ilkeler, örgütün ilkeleri, mesleki ilkeler ve toplumsal ilkeler. Tüm bunlar bir etik çerçevesi ve arka planı oluşturmaktadır (Evers, 2010(a), 52-53). Oğuzhan Taş ise, medya etiği ile ilgili çalışmasında neo-liberal politikalarla piyasa güdümüne giren ve holdingleşen medyanın, ticari haberciliğin toplumsal sorumluluk prensibinden uzaklaştığını ve buna çare olarak da medya etiğinin, piyasanın bu manipülatif gücünün panzehiri olarak işlev görebileceğini söylemekte, gazetecilik etiğini tarihsel gelişim sürecinde ele almaktadır (Taş, 2010, 3-4). Konuya ilişkin bir başka önemli çalışma, Süleyman İrvan'ın Medya ve Etik makalesidir. Bu çalışmaya göre medyada yaşanan etik sorunlar; haberde doğruluk sorunu, haber ve yorum ayrımının zorlaşması, haber ve reklam ayrımının yapılamaması, özel yaşama müdahale, kişilik hakları, eleștiri sınırlarının aşılması, ayrımcılık, haber kaynaklarıyla ilişkiler, haber kaynağının gizliliği, çocuklara ilişkin haberlerde yaşanan etik sorunlar, cinayet, intihar gibi trajik olaylara ilişkin etik sorunlar, haber için etik dışı yöntemlerin kullanılması ve paralı haberciliktir (İrvan, 2005, 69-89). Medya etiği ile ilgili çalışmalar genellikle, gazetecilik mesleğini yaparken uyulması gereken bireysel ve kurumsal profesyonel kodlar yaratma ve uygulamadaki sorunlar üzerine odaklanmaktadır.

İnternet gazeteciliği ya da yeni medya, bu etik sorunların bir kısmını kapsamaktadır. Ancak yeni medya ortamının doğasının, içerik üretiminin, yazılı basından farklılığı bunlara ek olarak yeni birtakım etik sorunları da beraberinde getirmiştir. Türkiye'de gazetecilerin sorumlulukları Basın Kanunu, Türkiye Gazeteciler Cemiyeti (TGC) Hak ve Sorumluluk Bildirgesi (http://www.tgc.org.tr, Erişim: 06.04.2018), Basın Konseyi Meslek İlkeleri (http://www.basinkonseyi.org.tr, Erişim: 06.04.2018) gibi yasal düzenlemelerle belirlenmesine karşın, söz konusu düzenlemelerin tamamı geleneksel gazeteciliği referans almakta ve internet gazeteciliğinin gereksinimlerini karşılamamaktadır. Bu nedenle yeni bir çalışma alanı olarakyeni medya gazeteciliğinde etik konusunun incelenmesi ve geliştirilmesi gerekmektedir (Korap Özel, 2016).

İnternet gazeteciliği ve yeni medyada etik sorunlara ilişkin ilk çalışmalardan biri; Andrew Belsey ve Ruth Chadwick'in Medya ve Gazetecilikte Etik Sorunlar 
(1998) adlı derleme kitabıdır. Kitabın Gazeteciler İçin Davranış Kodları adlı bölümünde elektronik medya adı altında internet gazeteciliği de ele alınmakta ve bildik profesyonel gazetecilik ilkeleriyle elektronik medyadaki etik sorunların giderilemeyeceği vurgulanmaktadır.

Günseli Bayraktutan (2012) da yeni medyanın yöndeşme ve etkileşimlilik özelliklerinin etik sorunlara yol açtığını söylemekte, örneğin cep telefonuyla çekilen bir fotoğrafın izin almaksızın ve telifi göz önünde bulundurmadan hızla yayılmasının daha önce hiç karşılașılmayan etik boyutları olduğunu ifade etmektedir. Bayraktutan, yeni medyanın etkileșimlilik özelliğinin ve hız unsurunun, bu alanı, geleneksel medyadaki etik tartışmalardan farklılaştırdığını söylemektedir. Ona göre; "etik muhakeme zaman ister, neyin doğru neyin yanlış olduğuna karar vermek için bir süre gerekir, ancak yeni medyada her şey hızlı gelişmektedir. Araç bunu kolaylaştırır, beklentiler de hızlı olmanızı ister. Hızlı güncelleme ve tepki bu yeni ortamın en önemli özelliğidir... Hız ise etik muhakemeyi zaman zaman ihmal etmenize neden olabilecek bir faktördür" (Bayraktutan, 2012, 251). Dijital gazetelerin, rakiplerinden farklılaşmasındaki en önemli etmenlerden biri hızdır, bir haberin rakiplerden önce girilmesi, o gazetenin arama motorlarında üst sıralarda çıkmasına, dolayısıyla reklam verenler açısından daha cazip olmasına yol açmaktadır. Hızın bu kadar önemli bir belirleyici olması ise internetten edinilmiş ve teyit edilmemiş yanlış bilgilerin yayılmasına - dijital gazetecilik güncelleme imkânı da sağladığından sonradan düzeltilmek üzere- daha kolay olanak tanımaktadır.

Etik ve gazetecilikle ilgili başka bir makale, farklı ülkelerde uygulanan habercilik etik kodlarını incelemiş ve gazeteciliğin dijitalleştiği gerçeği üzerinden bu ilkelerin güncellenip güncellenmediğini araştırmıştır (Campo \& Boj, 2015, 740). Campo ve Boj, bu çalışmalarında, 99 ülkedeki etik kodları analiz eden bir araştırma yapmış ve sadece 9 ülkenin etik kodlarının dijital gazetecilikle uyumlu hale getirildiği sonucuna ulaşmışlardır. Dijital gazetecilik etik ilkeleri konusunda en güçlü ülkelerin Kanada, Birleşik Krallık ve Norveç olduğu belirtilmiștir (Campo \& Boj, 2015, 740).

Dijital gazetecilik ve etik konusuna ilişkin çalışmalar genellikle uygulamadan doğan sorunları ele almaktadır. Bu bağlamda en kapsamlı çalışmalardan biri, Mutlu Binark ve Günseli Bayraktutan'a ait Ayın Karanlık Yüzü: Yeni Medya ve Etik (2013) adlı kitaptır. Bu kitapta, akademisyen, STK temsilcisi, aktivist ve medya profesyonelleriyle görüşülerek, yeni medyanın doğurduğu etik sorunlara ilişkin görüşler ortaya konmuştur. Bu çalışmaya göre, yeni medyanın doğurduğu etik sorunlar şunlardır (Binark \& Bayraktutan, 2013, 39):

- Özel yaşamın gizliliği

- Telif-patent hakları

- İçeriğin asıl kaynağının gösterilmemesi

- Üretilen içeriklerin doğruluğu teyit edilmeden yayımlanması

- Kişisel verilerin güvenliğinin sağlanamaması

- Veri madenciliği

- Dijital gözetim

- Haber ve ticari enformasyonun sinırlarının belirsizleşmesi

- Yeni medya ortamındaki yoğun reklam içeriği

- Yanıltıcı etiketleme ve başlıklandırma

- Nefret söylemi

- Bireyin yeni medya ortamında sadece tüketici olarak konumlandırılması. 
Haluk Geray ve Aylin Aydoğan ise, yeni iletişim teknolojilerinin gazetecilikte yarattı̆̆ı etik sorunları; "görüntüyle oynama, bilgi yanılsaması, sosyalleşme sitelerinin amacı dışında kullanımı, içeriğin izinsiz ve/veya kaynak göstermeden kullanımı, reklam-haber ayrımının kaybolması, profesonel-kullanıcı ayrımının zorlaşması" (Geray \& Aydoğan, 2010, 310-317) olarak belirtmektedir. Evers'e göre yeni medyadaki etik sorunlar; "haber ile ticari enformasyon arasındaki sınırların belirsizleşmesi, online içeriğin çok hızlı bir şekilde yayınlanması, başka bir deyişle prematüre olması, hatalara daha kolay yol açan bir mecra olması, haber siteleri ya da bloglardaki enformasyona güvenirlik, gazeteci yurttaş ayrımının birbirine karışması"dır (Evers, 2010(b), 328).

John V. Pavlik'in "New Media and Journalism" (2001) adlı kitabı da alandaki önemli çalışmalardan biridir. Kitap, dijitalleşmenin gazetecilik üzerindeki etkilerini kapsamlı bir şekilde ele almasının yanı sıra, gazetecilik etiği ve yeni medya başlıklı bölümde, dijital ortamlarda haber toplamada, haber üretiminde, online haber içeriğinde gazeteciliğin karşı karşıya kaldığı etik sorunların bir çerçevesini çizmeye çalışmış ve öneriler getirmiştir. Pavlik, haber toplamada karşılaşılan etik sorunlar olarak; gizli kamera kullanımını ve internetten edinilen ve kontrol/teyit edilmeyen belge ve kayıtları belirtmektedir. Dijital haber üretiminde karşılaşılan etik sorunlar olarak ise; dijital manipülasyon, onaylanmamış elektronik bilgi kullanımı, așırı enformasyon, telif hakkı ve mahremiyet yasalarının ihlali maddelerini saymaktadır. Online içeriğe dair endişelerle ilgili ise, normalde basılı bir gazetede bir haberin başında yer almayacak reklamların, bannerların, tanıtımların dijitalde büyük oranda yer alması, yer kaplaması ve haber ile reklam ayrımının karışmasını belirtmektedir. Bununla ilgili olarak, haber ile reklam/tanıtım içeriğinin tüm sayfada açık bir şekilde ayrılmasını, 'tanıtım/advertorial' etiketinin açık bir şekilde yazılmasını, reklam içeren ama habermiş gibi görünen içeriklere hiçbir editörün başvurmamasını, haber içeriğine reklam linki konulmamasını önermektedir (Pavlik, 2001, 82- 92). Pavlik, Media in the Digital Age kitabında ise, özellikle sitelerin kopyalanması ve izinsiz kullanılması ile ilgili etik sorunlara değinmekte ve site intihallerini önlemenin yollarına dair öneriler getirmektedir (Pavlik, 2008, 234-266).

Dijital habercilikte okurun maruz kaldığı etik sorunlar bağlamında literatürde en çok üzerinde durulan konuların biri tık yemi/tık tuzağıdır (clickbait). (Blom \& Hansen, 2015, 87-100, Chen \& Conroy \& Rubin, 2015, 15-19, Özyal, 2016, Dönmez, 2010, Işı \&Koz, 2014). Bu çalışmalardan Blom ve Hansen 10 farklı Danimarka haber web sitesi örnekleminde okuyucunun tıklatan/merak uyandıran başlıkların online haber gazeteciliğinde kullanımının haritasını çıkarmıştır. Bu çalışmaya göre; basında ticarileşmenin ve tabloidleşmenin Danimarka online haber başlıklarında tıklanmadan içeriği anlaşılmayan başlık kullanımının yeniden ortaya çıkmasına liderlik ettiği görülmektedir. Ticari ve tabloid medyada, ticari ve tabloid olmayan medyaya oranla tıklatan başlıkların kullanımının daha yaygın bir eğilim olduğu görülmüştür. Tıklatan / merak uyandıran başlıklar temel olarak okurları tıklamaya ve tüm haberi okutmaya yönlendirici tık tuzağı olarak kullanılmakta, böylece haber sitelerini reklam verenler için daha çekici hale getirmektedir (Blom \& Hansen, 2015, 98).

Chen, Conroy ve Rubin'in çalışmalarında ise; online gazeteciliğin tabloidleşmenin yeni bir formu olarak tık tuzağını ortaya çıkardığı söylenmekte ve tık tuzağı; temel amacı dikkat çekmek ve ziyaretçileri o linke tıklamaya cesaretlendirmek 
olan içerik olarak tanımlanmaktadır. Tık tuzağı, online gazetecilikte söylentinin ve yanlış enformasyonun hızlı yayımının bir karıșımıdır ve bu tür haberler yanlış haberlerdir (Chen \& Conroy \& Rubin, 2015, 15). Benzer bir yaklașımı Ișık ve Koz (2014) çalışmalarında ele almışlar ancak yanlış haber ifadesi yerine "çöp haber" demeyi tercih etmişlerdir. Çöp haberlerle ilgili Işık ve Koz şunları söylemektedir: "Reklam gelirlerinden daha fazla pay almak adına arama motorlarını, internet kullanıcılarını ve reklam verenleri manipüle eden bu tür siteler, kullanıcılara çoğu zaman, 'anahtar' olarak nitelendirilen kelime dizinlerinden oluşan, haber değerlerinden uzak içerikler sunmakta ve bu yolla meşru olmayan kazançlar elde etmektedirler. Bu tür internet haber siteleri, kimi zaman henüz açıklanmamış sınav sonuçlarıyla kullanıcıları sitesine çekerken, kimi zaman da 'tuzak başlıklarla' hem bu hizmeti sunan arama motorlarını hem de internet kullanıcısını yanıltmaktadır." (Işık \& Koz, 2014, 27). Hakan Dönmez ise, tık tuzağına düşüren başlık ve içerikleri 'kapan manşetler' olarak ifade etmektedir. Kapan manşet; "haber değeri varmış izlenimi uyandıran ve yakınlık, korku, endişe, merak, heyecan uyandıracak bir dille oluşturulan bu haber başlıklarına yüklenen rol, Cursor (imleç) tam da başlığın üstüne denk gelecek biçimde, okurun mouse'u (fareyi) tıklatmasını sağlamaktır. $\mathrm{Bu}$ noktada genellikle tıklanan haber başlığ paralellik, birlik ve bütünlük gözetilmemektedir." (Dönmez, 2010, 105). Burak Özyal ise; tık tuzağı ile ilgili Türkiye'deki önemli haber web siteleri üzerinde yaptığı araştırmasında tık tuzağı haberciliğinin 9 şekilde ortaya çıktığı sonucuna ulaşmıştır. Bunlar; yarım cümle ile kurulan haber sunumları, öznenin ya da nesnenin gizlendiği haber sunumları, referans kelimeler üzerinden kurulan haber sunumları, klasik tık odaklı haber sunumları, görüntünün ön planda olduğu haber sunumları, şok-flaşbomba-son dakika temalı haber sunumları, karma kategori, haberin içerisinden seçilen cümle-cümlelerin veya anahtar ifadelerin kullanıldığı haber sunumları, gazetenin yorumunun veya değerlendirmesinin başlık olarak kullanıldığı haber sunumlarıdır (Özyal, 2016, 296). Türkiye dijital gazetelerinde Özyal'ın kategorize ettiği türdeki başlıklara sıklıkla rastlanmaktadır. Örneğin; bu çalışmanın yapıldığı tarihte yapılan kısa bir taramada tıklanma oranı bakımından üst sıralarda yer alan dijital gazetelerde şu başlıklara rastlanmıştır: "Ünlü sanatçıdan kötü haber", "UEFA' dan flaş karar!” “Galatasaray'a.....,, "Annesini gören....., "Türkiye'nin en itibarlı meslekleri belli oldu. İlk sırada...", "O adada her şey serbest”, "Bir ilçenin gözyaşları", "Bir banka daha adını değiştirdi”.
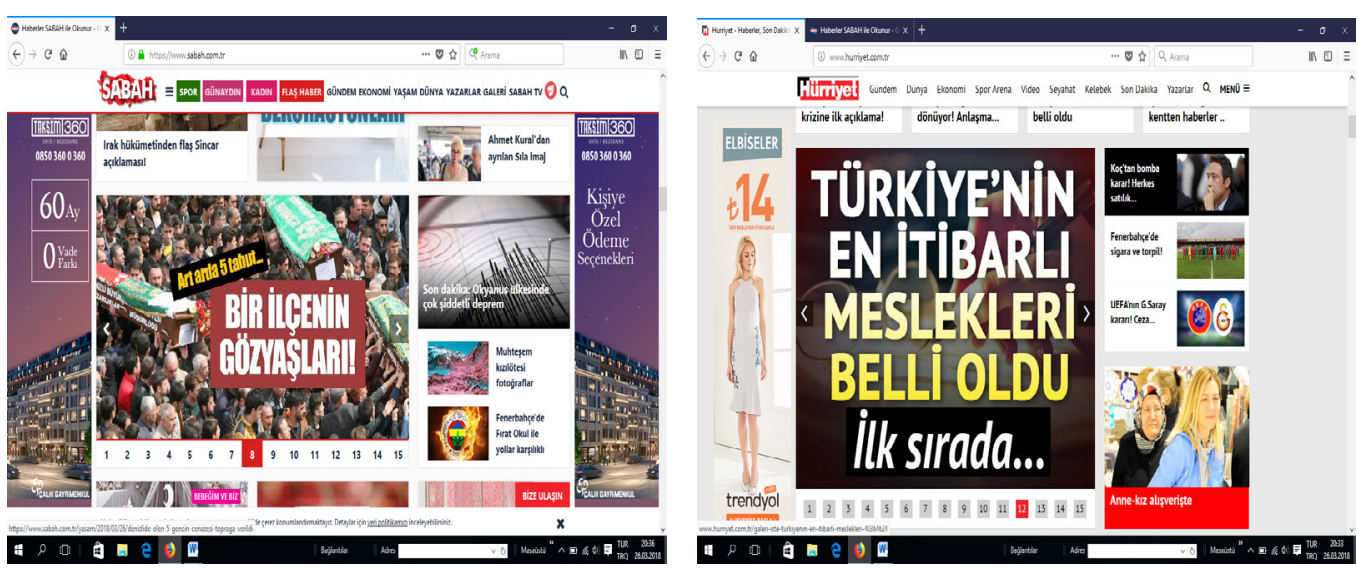

Resim 1: Sabah ve Hürriyet gibi ana akım gazetelerin web sitelerinde de tıklatmaya yönelik başlık kullanımlarına sıklıkla rastlanmaktadır. 
Özneyi / nesneyi gizleme, yarım ifadeler, arama motorlarında en çok aranan anahtar kelimelerin başlık içine sıkıştırılması ve tekrar edilmesi en çok kullanılan stratejilerdir. Bu tür haber başlıkları, merak uyandırmakta ve haberin içine girmeden aslında haberin neyi anlattığı anlaşılmamaktadır. Okur, habere tıklamadan içerikle ilgili ya hiçbir fikre sahip olmamakta ya da yanlış bir kanıya kapılmaktadır. $\mathrm{Bu}$ başlıkların temel özelliği eksik ya da yanlış bilgi vermektir.

Literatürde üzerinde durulan başka bir önemli konu ise; dijital gazetelerde reklamcılık faaliyetinin etik açıdan sorun yaratacak şekilde yapılmasıdır. Buradaki en temel sorun reklam- haber ayrımının güçleşmesidir. Dijital gazetelerde özellikle manşetlerin arasına sıkıştırılan ve ilk anda anlaşılmayan reklamlar ve haberin üstünde, haber boyutunda verilen reklamlar, ciddi anlamda etik sorunlara yol açmakta, haberle reklamın ayırt edilememesi sonucunu doğurmaktadır. Konuyla ilgili olarak Pavlik, basılı bir gazetede haberin başında yer alamayacak reklamların, bannerlerin, tanıtımların dijitalde büyük oranda kullanıldığını söylemektedir. Pavlik'in online gazetelerde ideal ve etik kurallara uygun bir reklamcılık için önerileri şunlardır ((Pavlik, 2001, 82- 92): Haber ile reklam/tanıtım içeriğinin tüm sayfada açık / anlaşılır bir şekilde ayrılması, "tanıtım/advertorial" etiketinin açık bir şekilde yazılması, reklam içeren ama habermiş gibi görünen içeriklere hiçbir editörün başvurmaması, haber içeriğine reklam linki konulmaması. Özlem Kalan ise yeni medya ortamında reklamla ilintili etik sorunlar olarak; haber - reklam ayrımının kaybolması, reklamın belirsizleştirilmesi, viral reklam, oyun içi reklam, gerilla reklam, reklam kirliliği, mobil reklamcılık, kişisel verilerin ticari amaçlı kullanımı gibi etik sorunlardan söz etmektedir (Kalan, 2016, 78-86). Reklam, dijital gazeteler için en önemli gelir kaynağıdır ve haberin içine gizlenmiş reklamlar kullanılan en yaygın stratejilerdir. Ancak bu uygulamalar, başlangıçta o reklamın görüntülenmesini sağlarken, uzun vadede okur tepkisine ve okurun uzaklaşmasına yol açmaktadır.

Dijital gazetelerde okurların hem neden olduğu, hem maruz kaldığı en önemli etik sorunlardan ikisi siberzorbalık ve nefret söylemidir. Bu durumların cereyan ettiği en önemli alan ise haberlerin altına yapılan okur yorumlarıdır. Okur yorumları, bir kamusal tartışmaya ve diyalojik iletişime olanak verebilecek bir imkâna sahipken, ortaya çıkan etik ihlaller nedeniyle, bugün dijital gazetelerde kaldırılmaya başlanmıştır. Sabah.com.tr ve ahaber.com.tr okur yorumlarını kaldırmıştır, sadece sosyal medyadaki okur yorumları durmaktadır. www.hurriyet.com.tr yetkilileri ise başlangıçta okurlar için bir tartışma platformu yaratma gibi ideal bir amaçla yola çıktıklarını, ancak daha sonra tahakküm ve siber zorbalık nedeniyle yorumlara kısıtlama getirmek zorunda kaldıklarını söylemişlerdir. www.milliyet.com.tr'de de okur yorumları kaldırılmıştır, onun yerine habere ifade bırakma seçeneği kullanılmaktadır. Elif Korap Özel, okur yorumlarında karşılaşılan etik sorunları, profesyonel gazetecilerle görüşerek ortaya koymuştur. Özel, gazetecilerin verdiği yanıtlar doğrultusunda okur yorumlarında karşılaşılan etik sorunları 7 kategoride toplamıştır. Bunlar; "nefret söylemi” (Küfür/ hakaret, şiddeti meşrulaștıran ifadeler, ırkçlık ve ayrımcılık, intiharı teşvik, beddua, alay - küçümseme), "mahremiyetin ihlali" (Cinsel hayatın, sağlık durumunun, dini inancın mahremiyetinin ihlali), "siber kabadayılı" (Okurların birbiriyle tartışması, okurun gazeteye/gazeteciye hakaret etmesi, tehdit, habere konu kişilere yönelik linç, iftira/ yanıltıcı bilgi, argo ifadeler), "yasadışı içerik" (Terör propagandası, pedofil-grooming, finansal suçlar vb.), "okur yorumlarının sansürlenmesi" (Gazeteler tarafından sadece egemen söylemle örtüșen 
okur yorumlarının yayımlanması, eleştirel görüşlerin sansürlenmesi), "okurların reklam içeriği yayınlaması" ve "dijital gözetim"dir (Korap Özel, 2016, 2010).

Yeni medyada etik sorunlara ilişkin literatürün, genellikle yeni medya ortamının özelliklerinin yaratabileceği sıkıntılar, bizzat uygulamadaki deneyimlerinden doğan etik problemlerve bunlara karşı geliştirilebilecekçözüm önerileriüzerineodaklandığı görülmüştür. Bu çalışma konuyu daha spesifik olarak internet gazeteciliği özelinde ele almayı ve gazetecilerin konuya ilişkin görüşlerini araştırmayı amaçlamıştır.

\section{Araştırmanın Yöntemi, Örneklemi ve Önemi}

$\mathrm{Bu}$ çalışma, dijital gazeteciliğin gazetecilik mesleğine yönelik etkilerini ve ortaya çıkardığı etik sorunları medya çalışanları gözüyle ortaya koymayı amaçlamaktadır. Çalışma ile dijitalleşmenin habercilik ve gazetecilik mesleği açısından etkileri ve internet gazeteciliğinde karşılaşllan etik sorunlara ilişkin gazetecilerin görüşlerini ortaya koymak hedeflenmiştir.

Araştırma, şu sorulara yanıt bulmayı amaçlamaktadır: Gazetecilere göre;

- Dijitalleşmenin gazetecilik üzerindeki olumlu etkileri nelerdir?

- Dijitalleşmenin gazetecilik üzerindeki olumsuz etkileri nelerdir?

- Gazetecilere göre internet gazeteciliğinde habercilikle ilgili karşılaşılan etik sorunlar nelerdir?

- Gazetecilere göre internet gazeteciliğinde okur açısından karşılaşılan etik sorunlar nelerdir?

Çalışma kapsamında veri toplama aracı olarak nitel araştırmalarda en sık kullanılan veri toplama araçlarından görüşme tekniği kullanılmıștır. Bu çalışmada Patton'un (1987), görüşme yaklaşımlarından "görüşme formu tekniği"ne başvurulmuştur. "Patton, üç tür görüşme yaklaşımından söz etmektedir: sohbet tarzı görüşme, görüşme formu yaklaşımı ve standartlaştırılmış açı uçlu görüşme. Göre görüşme formu yaklaşımında görüşmeci, önceden hazırladığı konu veya alanlara sadık kalarak, hem önceden hazırlanmış soruları sorma, hem de bu sorular konusunda daha ayrıntılı bilgi alma amacıyla ek sorular sorma özgürlüğüne sahiptir. Görüşme formu, araştırma problemi ile ilgili tüm boyutların ve sorunların kapsanmasını güvence altına almak için geliştirilmiş bir yöntemdir" (Yıldırım ve Şimşek, 2013, 149150). Bu çalışmada dijitalleşmenin gazeteciliğe etkilerini ortaya koymak amacıyla, Türkiye'de web siteleri en fazla ziyaret edilen ulusal gazetelerin internet editörleri ile görüşülmüştür. Görüşme formu, gazetecilerin görev tanımları ve deneyimlerine ilişkin sorular, dijitalleşmenin gazetecilik mesleği üzerindeki etkilerini ortaya koyma amacına yönelik, dijitalleşmenin gazetecinin iş yapma biçimi üzerindeki etkilerini ortaya koyma amacına yönelik, internet gazeteciliğinde habercilik ve okur açısından ortaya çıkan etik sorunlara ilişkin görüşlerini ortaya koymaya yönelik soruları kapsayan dört bölümden oluşmuștur.

Görüşmeler sonucunda elde edilen veriler ise kodlanarak sınıflandırılmış ve içerik analizi yöntemiyle sistematik hale getirilerek sayısal verilere dönüştürülmüş, böylece gazetecilerin konuya ilişkin görüşleri ve eğilimleri belirlenmeye çalışılmıştır.

Araştırma kapsamında görüşülecek gazetecilerin tespit edilmesinde ise amaçlı örnekleme yöntemine başvurulmuştur. "Olasılık temelli örnekleme yöntemlerinin tersine amaçlı örnekleme yöntemleri, tam anlamıyla nitel araştırma geleneği 
içinde ortaya çıkmıştır. Patton'a göre, olasılık temelli örnekleme temsiliyeti sağlama yoluyla evrene geçerli genellemeler yapma konusunda önemli yararlar sağlarken, amaçlı örnekleme zengin bilgiye sahip olduğu düşünülen durumların derinlemesine çalışılmasına olanak vermektedir" (Yıldırım ve Şimşek, 2013, 135). Bu çalışmada da dijitalleşmenin gazetecilik pratikleri üzerindeki etkisi ve internet gazeteciliğinin ortaya çıkardığ bizzat gazetecilikte dijitalleșme pratiğinin ilk elden deneyimleyicisi olan internet editörlerinin görüșlerine başvurularak araştırma sorularına yanıt bulabilmek için amaçlı örnekleme yapılmıştır. Böylece konu hakkında en fazla gözlem ve deneyime sahip olduğu düşünülen özel bir kitlenin görüşlerine ulaşılarak, araştırma soruları hakkında derinlemesine bilgi elde edilmesi amaçlanmıştır.

Bu kapsamda pek çok araştırmaya kaynaklık eden www.alexa.com (Erişim: 07.02.2018) sitesi verilerine göre Türkiye'nin en fazla ziyaret edilen ulusal gazete web sitelerini yayına hazırlayan internet editörleriyle irtibat kurulmuş ve randevu alınarak görüşmeler 15-20 Ocak 2018 tarihleri arasında İstanbul'da gerçekleştirilmiştir. Araştırmanın yapıldığı tarihte Doğan Medya Grubu bünyesinde yer alan www.hurriyet.com.tr'den ${ }^{1}$ 5, Demirören Medya Grubu sahipliğindeki www. milliyet.com.tr'den 5 ve Turkuaz Medya Grubu mülkiyetindeki www.sabah.com.tr ile ahaber.com.tr'den 5 olmak üzere toplam 15 gazeteci ile görüşülmüştür. Görüşülen gazetecilerin, kurumları, görevleri ve meslekteki çalışma süreleri izinleri alınarak Tablo 1'de gösterilmiştir.

Tablo 1: Araştırmada görüşülen gazeteciler, görevleri, kurumları ve meslekte çalışma süreleri

\begin{tabular}{|c|c|c|c|c|}
\hline Gazeteci & Görevi & Kurumu & $\begin{array}{l}\text { Meslekte } \\
\text { deneyim }\end{array}$ & $\begin{array}{l}\text { Dijitalde } \\
\text { deneyim }\end{array}$ \\
\hline Emre Kızılkaya & İçerik Koordinatörü & hurriyet.com.tr & 15 yll & $5 \mathrm{yll}$ \\
\hline İsmail Değirmenci & İnternet Editörü & hurriyet.com.tr & 20 yıl & $11 \mathrm{yll}$ \\
\hline Hülya Soyöz & Okur Yorumları Editörü & hurriyet.com.tr & 12 yıl & 12 yıl \\
\hline Sevin Turan & Dijital Medya İçerik Müdürü & hurriyet.com.tr & 10 yıl & $8 \mathrm{yll}$ \\
\hline Osman Yenilmez & $\begin{array}{l}\text { SEO (Search Engine } \\
\text { Optimization) Editörü }\end{array}$ & hurriyet.com.tr & 2 yıl 10 ay & 2 yıl 10 ay \\
\hline Bülent Ayanoğlu & Dijital Medya Koordinatörü & milliyet.com.tr & 33 yıl & 12 yıl \\
\hline Taner Şahin & İnternet Editörü & milliyet.com.tr & $8 \mathrm{yll}$ & $7 \mathrm{yll}$ \\
\hline Ayşegül Dönmez & İnternet Editörü & milliyet.com.tr & $10 \mathrm{yll}$ & $10 \mathrm{yll}$ \\
\hline Ercan Sarıkaya & Haber Müdürü & milliyet.com.tr & 20 yıl & 4 \\
\hline Hüseyin Özdemir & Dijital İçerik Yayın Koordinatörü & milliyet.com.tr & $11 \mathrm{yll}$ & $11 \mathrm{yll}$ \\
\hline M. Fatih Gediman & Yayın Yönetmeni & ahaber.com.tr & 12 yıl & $9 \mathrm{yll}$ \\
\hline Şevket Karayaka & Yayın Yönetmen Yardımcısı & ahaber.com.tr & $5 \mathrm{yll}$ & 2 yıl \\
\hline Ayşe Özdemir & İnternet Editörü & sabah.com.tr & $1 \mathrm{yll}$ & $1 \mathrm{yll}$ \\
\hline Ökkeş Koska & İnternet Editörü & sabah.com.tr & $9 \mathrm{yll}$ & $9 \mathrm{yll}$ \\
\hline Erkan Sevenler & İçerik Yöneticisi & sabah.com.tr & $25 \mathrm{yll}$ & $5 \mathrm{yll}$ \\
\hline
\end{tabular}

\section{Dijitalleşmenin Gazetecilik Faaliyeti Üzerindeki Etkilerine Dair Görüşler}

\section{Gazetecilere Göre Dijitalleşmenin Gazetecilik Faaliyetine Olumlu Etkileri}

Araştırma kapsamında dijitalleşmenin gazeteciliğe etkileri ile ortaya çıkan yeni etik sorunlar bir arada ele alınmıştır. Böylece ortaya çlkan yeni etik sorunların ardında yatan gelişmelerin de ortaya konabilmesi ve bir bütün içinde ele alınması amaçlanmıştır. Araştırmanın "dijitalleşmenin gazetecilik faaliyeti üzerindeki etkileri konusundaki görüşleri ortaya koyma” teması bağlamında, görüşülen gazetecilere 
ilk önce iletişim teknolojilerindeki gelişmenin gazeteciliği geleneksel formundan farklı olarak nasıl dönüştürdüğü, etkilerinin neler olduğu sorulmuştur. Gazetecilerin konuya ilişkin verdiği cevaplar Şekil 1'de gösterilmiștir.

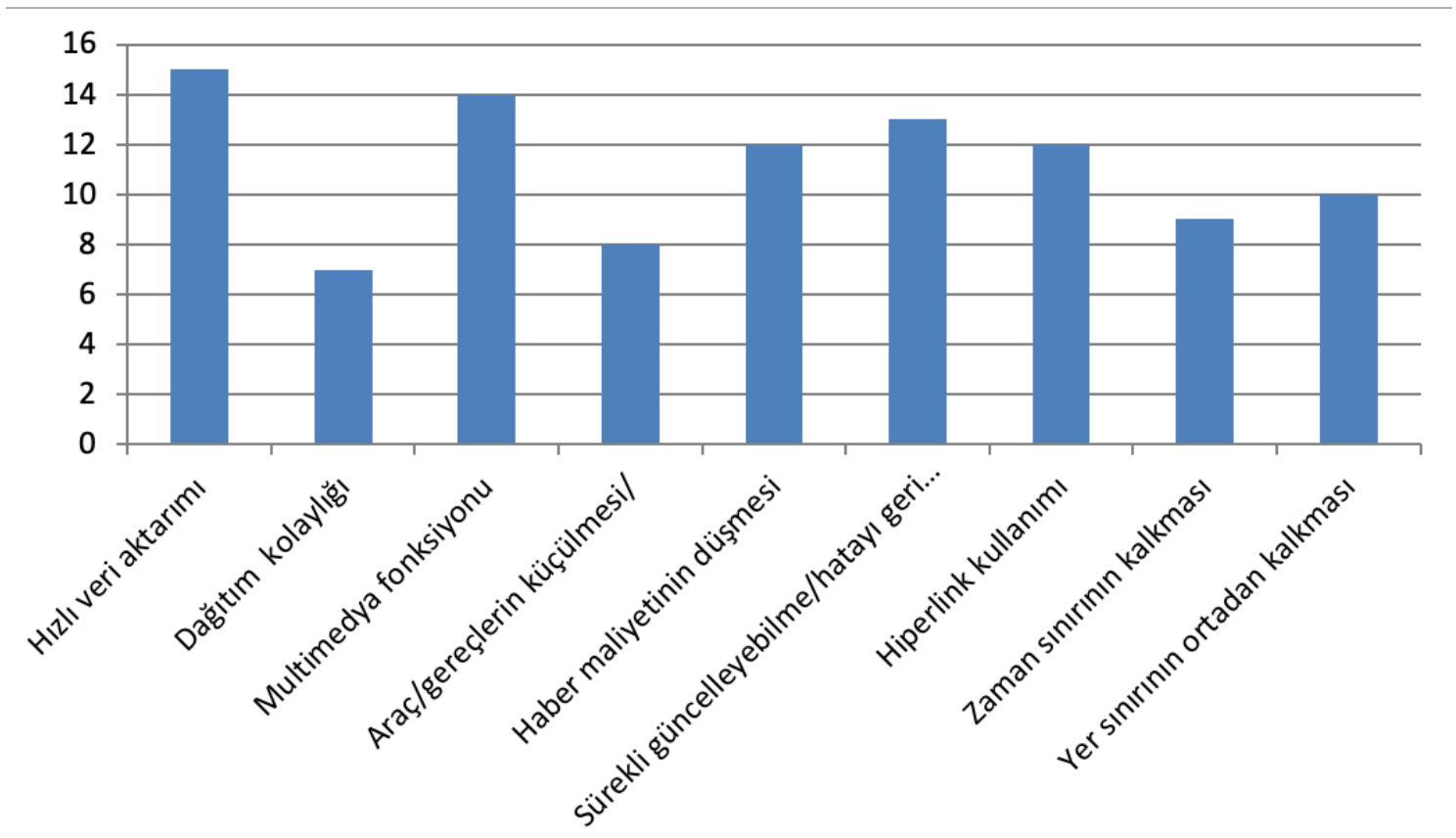

Şekil 1: Dijitalleșmenin gazetecilik faaliyetine olumlu etkileri

Yeni iletişim teknolojilerinin sağladığı olanaklar, geleneksel haber üretim süreçlerini tamamıyla değiştirmiştir. Nitekim çalışmaya katılan internet editörleri, görüşmelerde dijitalleşmenin gazetecilik mesleğine yönelik olumlu etkilerine sık sık değinmiştir. Araştırmaya katılan gazetecilerin tamamı (yüzde 100), hızlı veri aktarımını dijitalleşmenin gazeteciliğe yönelik en önemli katkısı olarak gördüklerini söylemiştir.

Gazetecilere göre haber metni, ses ve görüntünün olay yerinden mobil internet bağlantısı ile aktarılabilir hale gelmesi hızın çok önemli olduğu gazetecilik mesleği açısından en önemli kazanımdır. Araştırmaya katılan gazetecilerin yüzde 93'üne göre dijitalleşmenin en önemli ikinci katkısı haberlerde görüntü, ses ve metnin bir arada yayımlanabilmesini ifade eden multimedya fonksiyonudur. Bu internet gazeteciliğini, gazete, radyo ve TV haberciliğine göre üstün kılan bir özelliktir. Multimedya fonksiyonu, hem okurun habere tutunmasını ve daha fazla vakit geçirmesini sağlarken, hem de bu özellik ne kadar iyi kullanılırsa dijital gazete de rakiplerinden o kadar farklılaşmaktadır. Görsel, işitsel, metinsel tüm iletişim biçimlerinin bir arada yer aldığı haberler, okurun sitenin içinde daha fazla kalmasını sağlamaktadır. Bu nedenle gazeteciler, haberi tüm iletişim ortamlarıyla yapılandırmaya çalışmaktadır.

Emre Kızılkaya gazetecilikte dijitalleşmenin, multimedya özelliği sayesinde haberi çok daha geniş boyutlu ve gazetenin sayfa sayısından bağımsız olarak sunabilme imkanı sunduğunu şu örnekle anlatmaktadır:

"Multimedya fonksiyonu daha çok çalışılmış, emek verilmiş işler sunmamızı sağlıyor. Okur deneyimini iyileștirmiş oluyoruz. Örneğin Kilis'e roket düştü. Roketin düştüğü evin içine 360 derece kamera soktuk. Okur evin içini gezebildi. Haberi sadece metinle ve iki fotoğrafla aktarmak yerine okura o deneyimi yaşatmaya çalışıyoruz." 
Araștırma kapsamında görüşülen internet editörlerine göre gazetecilikte dijitalleşmenin en önemli üçüncü katkısı ise haberlerin sürekli güncellenebilmesi ve buna bağlı olarak da yapılan hataların geri alınabilmesi olmuştur. Gazetecilerin yüzde 87'si haberlerin sürekli güncellenerek okura sürekli olarak taze bilgilerin/ görüntülerin sunulabildiğini; diğer taraftan bu özellik sayesinde gazete, TV ve radyo haberlerinden farklı olarak maddi bir hata ya da yanlış fotoğraf kullanımı gibi bir dikkatsizliğin saniyeler içinde telafi edilebildiğini vurgulamıştır. Dijital ortamların haberin güncellenmesine olanak tanıması, yeni bilgiler, belgeler, görüntüler, fotoğraflar geldikçe habere eklenmesine olanak tanımaktadır. Haberle ilgili hataların düzeltilebilmesi de dijitalin sürekli güncelleyebilme potansiyeli ile ilişkili olduğundan araştırmada bu iki başlık bir arada ele alınmıştır. Basılı gazetede, bir hatanın geri alınabilmesinin tek yolu ertesi gün özür yazısı ya da tekzip yayınlamakken, dijital gazetede haber istenilen her an güncellenebilmektedir. Resmi kurumlardan, okurlardan ya da başka kanallardan gelen habere ilişkin geri bildirimlerle haber yeniden yapılandırılabilmekte, hatalar düzeltilebilmektedir.

Görüşülen gazeteciler, haberlerde olan hataları en çok okurlardan gelen geri bildirimler sayesinde fark ettiklerini söylemişlerdir. Gazeteciler okurlardan gelen tepkileri izlediklerini ve bunlara önem verdiklerini vurgulamıştır. Gazeteci Bülent Ayanoğlu bu durumu; "Bazen okur bu fotoğraf yanlış diyor, onu değiștiriyoruz, okurdan böyle faydalanıyoruz. Kağıt gazetede ise böyle bir imkanımız yok" sözleriyle ifade etmektedir.

Görüşülen gazetecilerin yüzde 80'i ise baskı makinesi, kağıt, mürekkep gibi hammaddelere ve dağıtım ağına ihtiyaç kalmaması, haber ve bilgi kaynaklarına internet üzerinden erişilebilmesi nedeniyle ulaşım masraflarının azalması gibi nedenlerle habercilik maliyetlerinin internette TV ve gazeteye göre çok daha düşük maliyetli olduğunu söylemektedir. Hızlı veri aktarımı, sosyal medyanın bir haber kaynağı haline gelmesi, gazeteciliğin veri gazeteciliği, robot gazetecilik gibi masabaşında haber üretmeye olanak tanıyan uygulamaları, dijital gazetenin basım maliyetinin olmaması gibi durumlar haber üretim maliyetini oldukça düşürmüștür.

Yine gazetecilerin yüzde 80'i hiperlinklerin kullanımı ile haberlerin arşiv bilgilerinin ya da ilgili diğer haberlerin linklerinin haber içinde yer alabilmesini dijitalleşmenin olumlu etkileri arasında saymıştır. Gazeteciler bunu hem haberi derinleștirmek hem de okurun haberde kalmasını, dolayısıyla haberin askıda kalma süresini arttırmak için kullanmaktadır. Bir olaya dair bağlam ve ardalan bilgisi olabilecek geçmiş haber linklerini iliştirme okurun haberde daha fazla kalmasını ve site içinde daha fazla zaman geçirmesini sağlamaktadır.

Araștırmaya katılan internet editörlerinin yüzde 67'si TV haberlerinde sürenin, gazetede ise sayfa sayısının kısıtlı olduğuna dikkat çekerek internet haberciliğinde haberi kullanacak yer sorunun ortadan kalktığını, yüzde 60'ı ise baskı saati ya da yayın saati gibi kısıtlayıcı faktörlerin internet gazeteciliği için geçerliği olmadığını, bu tür bir bağımlılık olmadan günün her saati sıcak bir gelişmeyi okur/izleyici/ dinleyiciye aktarmanın mümkün olduğunu belirtmiştir.

Gazeteci Hüseyin Özdemir, gazetede tek bir manșet alanı varken, dijital gazetenin çok sayıda manşet alanına sahip olduğunu, üstelik gün içerisinde bunları güncelleyerek çok sayıda haberi okura manşetten aktarabilme avantajını ellerinde tuttuklarını şöyle anlatmaktadır: 
“Gazeteden farklı olarak internette daha fazla manşet alanımız var. Bu bizi rahatlatıyor. Bir gazetenin birinci sayfasında kullanabileceğiniz haber sayısı kısıtlı. İnternette 8-9 manşet alanımız olsaydı sadece ciddi haberleri kullanabilirdik. Ama şu an 5 tepemiz (sürmanşet), 10 tane küçük tepemiz ve 10 tane manşet alanımız var. Dolayısıyla 25'lik bir alandan söz ediyoruz. Doğal olarak bunların 5-6'sında çok ciddi haberlere yer verirken, ilgi çekici olan, okuru çekebilecek diğer haberleri de manşetten kullanma şansımız oluyor."

Diğer taraftan araştırmaya katılan gazetecilerin yüzde 53'ü gazetecilikte kullanılan araç/gereçlerin küçülmesi ve hafiflemesini, yüzde 47'si ise internet ile birlikte TV'de lisans alma, basılı gazeteyi dağıtma gibi sorunların ortadan kalktığını ve internetin bulunduğu her yere ulaşılabilmesinin bir dağıtım kolaylığı yaratmasını dijitalleşmenin olumlu etkisi olarak gördüğünü bildirmiştir.

\section{Gazetecilikte Dijitalleşmenin Haber Kaynakları Ve Haber Üretimine Etkisi}

Araştırmanın "dijitalleşmenin gazetecilik faaliyeti üzerindeki etkilerini ortaya koyma" teması kapsamında, ikinci alt kategori olarak dijitalleşmenin haber üretim süreçlerini, haber kaynağını nasıl değiştirdiğine dair gazetecilerin görüşleri ortaya koyma amaciyla sorular sorulmuştur. Gazetecilerin vermiş olduğu cevaplar şekil 2'de gösterilmiştir.

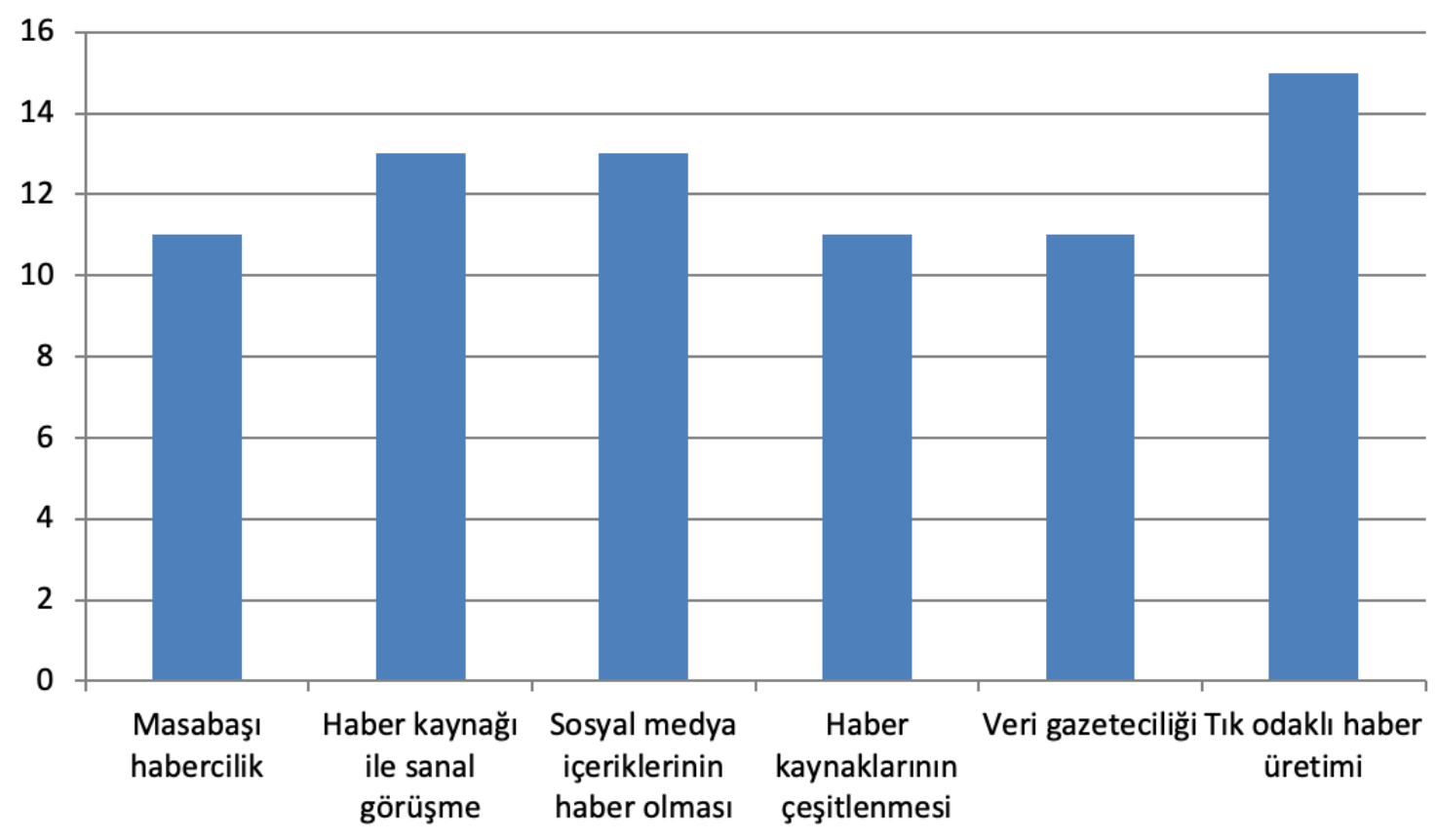

Şekil 2: Gazetecilikte dijitalleşmenin haber kaynakları ve haber üretimine etkisi

Araştırmaya katılan gazetecilerin tamamı (yüzde 100) haber üretim sürecinde "tıklanmanın" önemli bir kriter haline geldiğini vurgulamıştır. Geleneksel anlayıșta bir haberin yayın kararının verilmesinde önemlilik, ilginçlik, anilik, güncellik, yakınlık, gerçeklik, doğruluk, negatiflik, çatışma içerme, elit kişilerle/uluslarla ilgili olma gibi haber faktörleri etkili olurken, internet gazeteciliğiyle birlikte bu unsurların başına okurun habere ilgisini gösteren "tıklanma" rakamları gelmiştir. Gazeteciler, haberlerin tıklanma oranlarını sürekli olarak takip ettiklerini ve haberin kaderini belirleyen başlıca unsurun ise tıklanıp tıklanmadığı olduğunu vurgulamıştır.

Haber seçerken en fazla tıklanma rakamlarının önemli olduğunu aktaran Ayşegül Dönmez, şöyle konuşmuştur: 
“Internet, gazeteciliği nasıl etkiledi? Örneğin haberin nasıl seçileceğini değiştirdi. Gazeteden farklı olarak haberleri okunma oranını hesap ederek seçiyorsunuz. Haberlerin okunma oranı biçim için çok önemli. Artık yıllardır bu işi yaptığımız ve hangi haberin daha çok tıklanacağını bildiğimiz için sayfaya o minvalde haber seçiyoruz."

Ercan Sarıkaya da internet gazeteciliğinin tıklanmayı dikkate alan bir habercilik pratiği geliştirdiğini şöyle anlatmaktadır:

"Dijitalde sayfaya hangi haberin gireceğinde haberin okunması ile kamu yararını içermesi eşit oranda etkilidir, ama haber okunuyorsa sayfada kalır. Çünkü bu, haberimize ilgi olduğunu gösterir. Okunmuyorsa o haberi belirli bir süre sonra düşürmek zorunda kalırsınız."

Sevin Turan da internet dünyasının oyunun kurallarını yeniden yazması sonrası gazetecinin gazetecilik ilkeleri ile tıklanma hedefi arasında sıkışıp kaldığını şöyle anlatmıştır:

"Tıklanma haber seçiminde baktığımız en önemli kriter. Zaten hepimize tıklanma hedefleri konmuş durumda. Tıklanma önemli ama bizim için yine de her şey değil. Bazı haberler vardır hiç okunmasa da siz gazetecilik değerleri nedeniyle onu orada tutarsınız. Önemli olduğu için, haber değeri taşıdığı için, okunmasa da manşette tutarız, onu okutmaya çalışırız. Örneğin siyasi konular, gazetecilerin yargılanmasıyla ilgili haberler, mesleki bir gönül borcu, vefa nedeniyle bile hiç değilse o haberin orada durması gerekir diye düşünüyoruz."

İnternet gazeteciliğiyle birlikte okurun bir habere ilgisini gösteren tıklanma rakamlarının çok önemli hale geldiğini ifade eden Emre Kızılkaya ise tık almak için etik ilkelerden taviz vermemek gerektiğini söylemekte ve kendi uygulamalarından bir örneği anlatmaktadır:

"Bizim için elbette tıklanma da önemli haber değeri de. Ancak haber değeri taşıyan bazı şeyler yayın ilkelerine uymayabiliyor. Örneğin intihar haberleri konusunda hassasız. Özendirici olmamak için yayımlamıyoruz. Yayınlasak çok okunur ama etik gerekçelerle yayımlamıyoruz."

Görüşlerde de aktarıldığı gibi internet gazeteciliği gelenekselden farklı olarak "tık odaklı bir habercilik" pratiğini belirgin kılmıştır. Ancak gazeteciler tıklanma hedefine ulaşmaya çalışırken etik ilkelere de uyulmasının gerekliliğini önemle vurgulamaktadır.

Araștırmaya katılan gazetecilerin yüzde 87'sine göre ise gazetecilikte dijitalleşmenin haber kaynağı ve haber üretim süreciyle ilgili en önemli etkilerinden diğer ikisi, haber kaynağı ile e-posta ya da canlı görüşmeye olanak tanıyan Skype gibi programlar aracılığıyla internetüzerinden sanal görüşmeyapabilme ve sosyal medya içeriklerinin haber olabilmesidir. Günümüzde sosyal medyanın en önemli haber kaynaklarından biri olduğunu söylemek mümkündür. Görüşülen tüm gazetelerde sosyal medyayı takip eden ve oradan haberler üreten sosyal medya ekipleri vardır. Sevin Turan da gazetecilikte dijitalleşmenin sosyal medyayı bir haber kaynağı olarak tanımladığını şu örnek üzerinden anlatmaktadır:

"Dijitalleşmeyle birlikte haber kaynakları da değiști. Örneğin geçen seneden bir olay anlatayım. Kadıköy'de duran kedi heykeli çalındı. Normalde hiçbir ajans ya da gazeteci oraya gidip heykelin çalındığının haberini çekmez. Bu önemli bir haber değildir. Fakat vatandaşlar bunun fotoğrafını çekip Twitter'da paylaşınca ve olaya büyük bir tepki olunca biz bunu haber yaptık. Biz haber yapınca DHA da gidip bunu görüntüledi, orada esnafla konuştu. İș bu kadar büyüyünce çalan adam iki gün sonra heykeli geri 
getirdi. Sosyal medya olmasaydı böyle bir dünya yoktu. Sosyal medya bizim için Türkiye gündeminin görünümü, görünür hale gelmesi."

Dijitalleşmenin gazetecilikte haber kaynağı ve haber üretim süreçlerini nasıl değiştirdiğine dair soruya gazeteciler, ikinci sırada yüzde 73 katılım oranıyla haber kaynaklarının çeşitlenmesi, veri gazeteciliği ve masabaşı habercilik yanıtını vermiştir. Geleneksel habercilikten farklı olarak, yeni teknolojiler gazetecinin olay yerine gitmeden masabaşında haber yapmasına olanak tanımaktadır. Veri tarama ve analiz tekniklerinden yararlanan veri gazeteciliği, sosyal medyanın haber kaynağ olarak yaygın kullanımı, internet üzerinden veriye ulaşımın kolaylaşmasıyla birlikte haber kaynaklarının çeşitlenmesini sağlamıştır. Haber kaynaklarının bu şekilde internet dolayımıyla çeşitlenmesi, haber kaynağı ile sanal görüşme yapabilme firsatı, robot gazetecilik gibi uygulamalar ise teknolojik tabanlı masabaşında haber üretimine imkan sağlamaktadır. Gazetecilere göre masabaşı habercilik internetin haber kaynakları ve habere ulaşım yollarıyla ilgi yarattığı dönüşümün bir sonucu olarak ortaya çıkmıştır. Gazetecilere göre bu durum, sahada çalışan muhabirin öneminin azalmasına, editörün de iş tanımının daha kapsamlı hale gelmesine yol açmıştır. Editörler artık sadece haber edit ederek sayfa hazırlamamakta aynı zamanda geleneksel basındakinden farklı olarak "masabaşındaki editör/muhabir" olarak haber de yazmaktadır.

Sevin Turan, editörün rolündeki değişimi şöyle anlatmaktadır:

\begin{abstract}
"İnternette editörün işlevi değişti. Yazılı basından farklı olarak internet editörü gerektiğinde haber de yazar. Örneğin Münir Özkul KOAH'tan öldü. KOAH hastalığı ile ilgili sayfaya haber girmemiz gerekiyor. Biz hemen o haberi derler ve koyarız. Muhabirin yazmasını beklemeyiz. Oysa gazetede baskı saatine vakit varsa, editör haber merkezinden ister, haber merkezi haberi hazırlar editöre gönderir. İnternetteyse bunu bekleyecek zaman yok. Gerekirse yabancı bir siteden çeviri de yapabilir."
\end{abstract}

\title{
Internet Gazeteciliğinde Yaşanan Etik Sorunlara İlișkin Görüșler
}

Yukarıda da aktarıldı̆̆ı gibi dijitalleşmenin gazeteciliğe, haber pratiklerine, haber kaynağı ile ilişkilere yönelik ciddi etkileri olmuştur. Bulguların bu kısmında, aktarılmaya çalışılan etkiler doğrultusunda internet gazeteciliğinde yaşanan etik sorunlar gazetecilerin gözünden ortaya konacaktır. $\mathrm{Bu}$ çerçevede internet gazeteciliğinde ortaya çıkan etik sorunlar "habercilik bakımından" karşılaşılan etik sorunlar ve "okur bakımından" karşılaşılan etik sorunlar olmak üzere iki alt kategori de ele alınmıştır.

\section{Internet Gazeteciliğinde Habercilik Bakımından Karşılaşılan Etik Sorunlar}

Gazetecilere göre habercilik bakımından internet gazeteciliğinde karşılaşılan en önemli etik sorunlar Şekil 3 'te gösterilmiştir. 


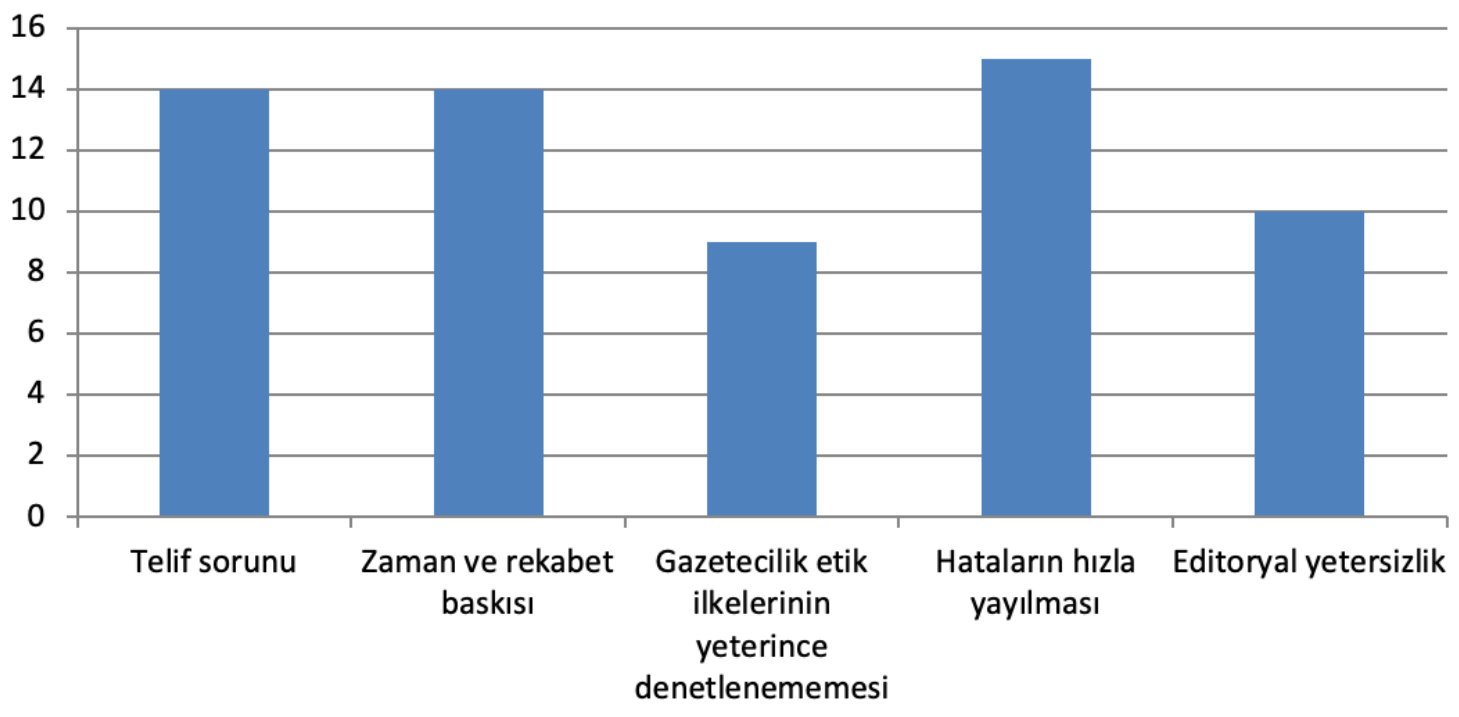

Şekil 3: Internet gazeteciliğinde habercilik bakımından karşılaşılan etik sorunlar

Gazetecilerin tamamı (yüzde 100), internet gazeteciliğinde hataların hızla yayılabilmesinin, habercilik bakımından önemli etik sorunlar yarattığını ifade etmiştir. Öncelikle internet gazeteciliğinde hata yapma olasılığı, haberleri işlemek için kâğıda göre daha az zaman bulunması nedeniyle artmaktadır. İnternette bir terör olayı ya da önemli bir siyasinin demeçlerini dakikalar içinde yayına hazırlamak gerekirken, gazetede baskı saatine kadar haber üzerinde çalışmak mümkündür. Diğer taraftan kâğıt gazetede bir haber baskıya hazırlanma sürecinde muhabir, haber şefi, editör, kontrolör, yazı işleri müdürü, genel yayın yönetmeni gibi pek çok kişi tarafindan görülmekte, kontrol edilmektedir. Sayfalar hazırlandıktan sonra ise "proof" denen sayfa çıktıları üzerinden haber bir de gazeteye girecek biçimiyle kontrol edilmekte, son olarak ise nihai baskıya geçmeden önce prova baskıda bizzat gazete kâğıdına basılmış hali son kontrolden geçirilmektedir. Bu nedenle kâğıt gazetede yanlış bir fotoğraf ya da bilginin fark edilme olasılığı artmakta, buna karşın bir kere baskıya girilip dağıtım yapıldıktan sonra artık hataları düzeltmek mümkün olmamaktadır.

$\mathrm{Bu}$ noktada görüşülen gazeteciler, her ne kadar internetin haberleri sürekli güncellemeye olanak tanıyan özelliğinin hataların düzeltilebilmesi için bir fırsat sunduğunu söylese de, hatalı bir metnin ya da görüntünün düzeltmeye fırsat bulamadan internet kullanıcıları tarafından saniyeler içinde kopyalanarak yayılabildiğini ve kısa süre içinde milyonlarca kişiye ulaşabildiğini vurgulamıştır. İnternet, teknik olarak hataları düzeltebilme olanağı sunsa bile birkaç saniye içinde "çok geç" kalınabilmektedir. Gazeteciler zaman zaman gazetecinin hız baskısı nedeniyle istemeden yaptığ bir hata nedeniyle birinin ya da birilerinin zarar görebileceğine, bunun da etik sorunlar doğuracağına dikkat çekmektedir. Örneğin tecavüze uğrayan genç kızla ilgili bir haberde genç kızın ismini kodlayan editör, haberin içinde tek bir yerde ismi açık unuttuğunda, bu bilgi çok kısa bir süre içinde sosyal medyada yayılabilmekte, haberdeki bu dikkatsizlik birkaç dakika içinde düzeltilse bile isim sosyal medyada çoktan duyulmuş olmaktadır. Gazeteci haberleri hem çok kısa sürede yayına hazırlamak hem de hata yapmamak zorundadır. Gazetecinin hatası nedeniyle büyük bir tepkiyle karşı karşıya kalabilmesi ve hatta işini kaybedebilmesi gazeteciler üzerindeki stresi bir kat daha artırmaktadır. ${ }^{2}$ 
Gazetecilerin yüzde 93'ü, haberi herkesten önce verme gerekliliğinden kaynaklanan rekabet ve zaman baskısının haberin doğrulanması, teyit edilmesi, hatasız ve eksiksiz olarak sunulması konusunda etik sorunlara yol açabildiğini ifade etmiştir. Gazeteciler zaman baskısı ve hatalar arasında ilişki olduğunu da vurgulamıștır.

Gazetecilerin yine yüzde 93'ü ise, internet gazeteciliğinde habercilik bakımından karşılașılan etik sorunlardan bir diğerinin, haberlerin izinsiz ve kaynakgösterilmeden paylaşılması yoluyla ortaya çıkan telif sorunu olduğuna vurgu yapmıştır. Emre Kızılkaya, telif sorunuyla ilgili yaşadıkları sıkıntıyı şöyle anlatmaktadır:

\begin{abstract}
"Şöyle bir şeyle de mücadele etmek zorundayız. Hürriyet'in bir yazarının köşe yazısını herhangi bir site alıp kullanabiliyor. Örneğin Ahmet Hakan'ın yazısını alıyor. Google'da Ahmet Hakan diye arandığında en üstte yazının orijinalinin bulunduğu Hürriyet'in linki değil, onu bizden izinsiz çalan haber sitesinin linki çıkıyor. İnsanlar onu tıklıyor. Bu da ciddi bir telif sorunu, etik sorun olarak karşımıza çıkıyor. Bir de bunu çalan sitenin linki Facebook'ta yayılıyor. İnsanlar Ahmet Hakan'ı Hürriyet yerine Hürriyet'ten çalan siteden okuyor."
\end{abstract}

Gazetecilerin yüzde 67'si ise editoryal yetersizliğin internet gazeteciliğinde etik sorunların ortaya çıkmasına yol açtığını ifade etmiştir. Çok ciddi yatırım gerektirmesi nedeniyle gazete ya da haber kanalı kurmak kolay olmadığı halde internet dolayımıyla çok sayıda küçük ölçekli haber sitesinin kolayca açılabilir hale gelmesinin gazeteci olmayanların da haber sitelerinde istihdam edilmesi ya da gazeteci olmayanların çeşitli amaçlarla kendi sitelerini kurmalarına yol açtığına işaret eden gazeteciler, bunun editoryal yetersizlikten kaynaklanan etik sorunların ortaya çıkmasına neden olduğunu ifade etmektedir. Gazetecilere göre bu durum doğrulanmamış, sansasyonel ve kalitesiz haber üretiminin artması ve dolaşıma girmesi sonucunu yaratmaktadır.

Gazetecilere göre editoryal yetersizlik, zaman ve rekabet baskısı bir araya geldiğinde ise haber faktörlerinin ve gazetecilik ilkelerinin yeterince denetlenememesi sorunu ortaya çıkmaktadır. Gazetecilerin yüzde 60'ı gazetecilikte dijitalleşmenin, internetin özellikleri nedeniyle gazetecileri çok hızlı habercilik yapmaya zorladığg ve bunun da haber faktörlerini ve gazetecilik ilkelerini denetlemeye ayrılan zamanın daralmasına yol açtığını vurgulamıştır. Bu nedenle geleneksel basında suçu henüz kanıtlanmamış bir zanlının fotoğrafını yüzü kapalı yayımlayan aynı gazetenin internet sitesinde dikkatsizlik sonucu fotoğraf yüzü açık biçimde yayımlanabilmekte ve etik açıdan sakıncalı durumlar ortaya çıkabilmektedir. (Söz konusu fotoğraf silinse bile, internet kullanıcıları tarafından görüntüsü alınmış ve milyonlarca kullanıcı tarafından dakikalar içinde paylaşılmış olmaktadır.)

\title{
İnternet Gazeteciliğinde Okur Bakımından Karşılaşılan Etik Sorunlar
}

Bu tema bağlamında ikinci alt kategori, internet gazeteciliğinde okurun maruz kaldığı etik sorunlardır. Bu konuya ilişkin gazetecilerin görüşleri şekil 4'te gösterilmiştir. 


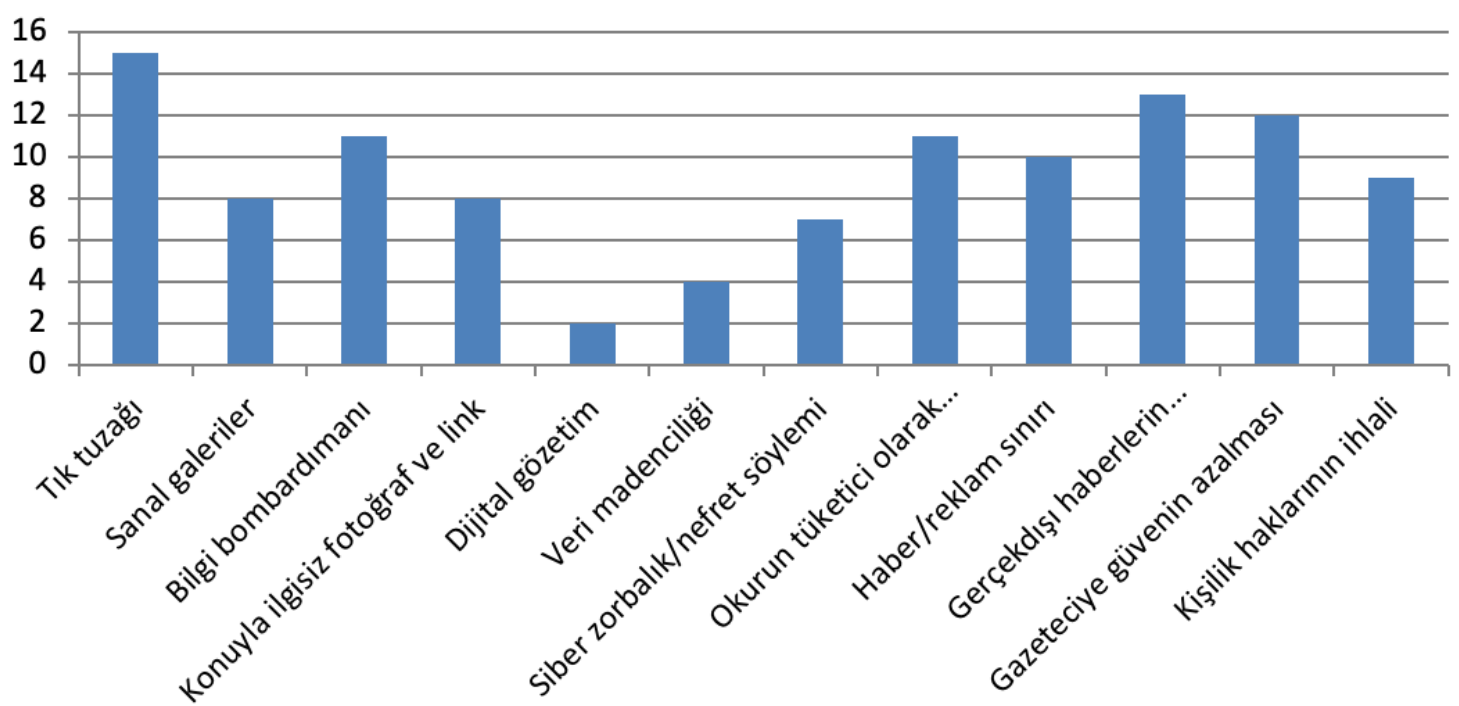

Şekil 4: İnternet gazeteciliğinde okur bakımından karşılaşılan etik sorunlar

Çalışma kapsamında gazetecilere internet gazeteciliğinde okur bakımından karşılaşılan etik sorunlar da sorulmuştur. Buna göre gazetecilerin tamamı (yüzde 100) okur açısından en büyük sorunun tık tuzağı (yanıltıcı başlık ve içerik) olduğunu söylemiştir. Gerçekdışı haberlerin hızla yayılması gazetecilerin yüzde 87'si ve internette gazetecinin ve haberin güvenirliğinin azalması gazetecilerin yüzde 80'i tarafından önemli sorunlar olarak gösterilmiştir. Gazetecilere göre diğer etik sorunlar ise sırasıyla okurun bilgi çöplügü ile karşı karşıya kalması (yüzde 73), okurun tüketici olarak görülmesi (yüzde 73), haber/reklam ayrımı arasındaki bulanıklık (yüzde 67), kişilik haklarının ihlali (yüzde 60), sanal galeriler (yüzde 53), konuyla ilgisiz fotoğraf ve link kullanımı (yüzde 53) ile siberzorbalık/nefret söylemi (yüzde 47). Veri madenciliği (yüzde 27) ve dijital gözetim (yüzde 13) ise gazeteciler tarafından en az karşılaşılan etik ihlaller olarak belirtilmiştir.

Gazetecilere göre okurlar açısından karşılaşılan en önemli etik sorun yanıltıcı başlık ve içerik kullanımı, diğer bir ifade ile clickbait/ tık tuzağıdır. Görüşülen gazeteciler yanıltıcı başlık kullanmama konusunda hassas olduklarını ifade ederken, bunu etik bulmadıklarını da söylemişlerdir. Fatih Gediman'ın konuya ilișkin görüșleri şöyledir:

“Clickbait'i okura saygısızlık olarak görüyorum. Bunun bir sahtekârlık olduğunu düşünüyorum. Bu hileyi yapan ve yapmayan haber mecraları arasında okur da ayrım yapıyor. Clickbait kısa vadede tık kazandırsa da uzun vadede okur kaybına yol açıyor. Okur gerçekten senin takipçinse bu saygısızlığı görünce seni terk ediyor. Bunu uzun süren tecrübemle gördüm diyebilirim. Ne yazık ki bazı haber siteleri bunu yapıyor. Ama kurumsal rakiplerimizi de içine katarak söyleyeyim, en azından bu uygulama geriye atıldı. Birinci manşetten, sürmanşetten bu tür şeyler yapılmıyor. Sosyal medyadan belki yapılıyor alabilir. Kurumsal haber sitelerinde artık daha dikkatli editörler."

Tık tuzağı ve yanıltıcı başlık ile ilgili olarak Ökkeş Koska ise şunları söylemiştir:

“Çok tıklanmak için clickbaite başvurmayız, çünkü biz merdiven altı bir haber sitesi değil büyük bir medya grubunun parçasıyız. Bazı siteler buna ne yazık ki başvuruyor. Okuru siteye getirmek için bir başlık atıyor, ama okur sitede onu bulamıyor. Bunu etik dişı buluyorum."

Gazetecilere göre internet gazeteciliğinde ortaya çıkan bir başka önemli sorun ise güvenirliktir. Gazeteciler, zaman baskısı nedeniyle haberlerin yeterince 
denetlenememesi ve işlenememesi, haber sitelerinin daha fazla okur çekebilmek için başvurdukları tık tuzakları, yanıltıcı başlıklandırma, hataların kolayca yayılabilmesi, gazeteci olmayanların da haber üretim sürecine dahil olması gibi nedenlerin gazetecinin güvenirliği konusunda sorunlar yaratabildiğini vurgulamaktadır.

Emre Kızılkaya bu konunun önemine dikkat çekmiştir:

\begin{abstract}
"İnternet gazeteciliğinde en önemli şey güvenilirlik. Öteki her şey, tık tuzakları vs. hepsi güvenilirliği etkiliyor. Güvenilirlik sayesinde okurla bağınızı daha güçlü kılabiliyorsunuz. Artık yayıncılar güvenilirliğe yatırım yapmaları gerektiğini gördü. Örneğin Independent, tamamen dijitale geçince siyasi haberlerde bile tıklanmayı baz alan bir dile geçiş yaparken The New York Times çizgisini hiç değiştirmedi. Bu onların (Independent) erişimini artırdı ama erişimle gelen gelir hiçbir zaman The NewYork Times'ın, The Guardian'ın güvenilirlikleri sayesinde gelen geliri, aboneliklerin getirdiğini getirmeyecek. Bu nedenle sadece tıka odaklanmak değil, güvenilirliğe yatırım yapmak uzun vadede yayıncılar için daha karlı olacaktır."
\end{abstract}

İnternet üzerinde pekçok haber sitesinde okurun tüketici olarak konumlandırılması ve reklam/haber ayrımının net olarak yapılamaması da gazetecileri rahatsız eden konulardan biri olmuştur. Gazeteciler, gazetenin yaşayabilmesi için reklam gelirinin bir zorunluluk, reklam geliri için de sayfa görünürlüğünün (tıklanma) önemli olduğunu vurgulamış, ancak habercilik kaygılarının bunun önüne geçtiğini ve haber alanını korumak için özen gösterdiklerini ifade etmiştir. Yanıltıcı galeriler de gazeteciler açısından internet gazeteciliğinde sorunlu bir alan görülmektedir. Emre Kızılkaya, sanal/yanıltıcı galerilerle ilgili şunları söylemiştir:

\begin{abstract}
“Galeriler sayfada geçirilen süreyi azaltıyor. Daha çok tıklıyorsun ama haberi 5 saniyede geçiyorsun. $\mathrm{Bu}$ da bizim haber kalitesiyle ilgili hedeflerimizle çelişiyor. Bir de şu önemli. İyi içerek var kötü içerik var. Örneğin bir otomobil fuarı haberinde fuardaki otomobillerin galerisi işlevseldir. Ama bazı haberlerde işlevine uygun değil. 0 rahatsız edici oluyor. Bazı haber sitelerinde haberi okuyabilmek için bütün fotoğrafları açmak gerekiyor ki, bu yanlıș."
\end{abstract}

Siber zorbalıkvenefretsöylemi degazetecilere göre internetgazeteciliği dolayımıyla ortaya çıkan etik sorunlardan biridir. Gazeteciler, özellikle okur yorumlarını denetlemeyen küçük çaplı haber sitelerinde gazetecilere ya da haberin konusu olan kişilere yönelik hakaretler ya da okurların birbirleriyle iftira ve hakarete dayalı ya da ırkçı, ayrımcı söylemler içeren tartışmalar yürütmesinin siber zorbalık ve nefret söylemi yarattığına işaret etmektedir. Siber zorbalığın ve nefret söyleminin yoğun olarak sosyal medya üzerinden yürüdügünü aktaran gazeteciler, zaman zaman okur yorumları üzerinden siber zorbalıkla karşılaşılabildiğini de anlatmıştır. Bu durum kurumsal gazetelerin okur yorumlarını yayından kaldırmasına, uygulamaya devam edenlerin de yorumları pre-moderasyon, bir başka ifadeyle ön denetim sonrası yayına almasına yol açmaktadır. Bu çalışma kapsamında Sabah ve Milliyet gazetelerinin önceden okur yorumlarını yayımladıkları halde bir süredir yayından kaldırdıkları, Hürriyet'in ise yorumları denetlemek için okur yorumları editörleri istihdam ettiği görülmüştür. Siber zorbalığın ve nefret söyleminin gazeteler üzerinde daha çok okur yorumları aracılığıyla gerçekleştiğini hatırlatan Hüseyin Özdemir, siber zorbalığı /nefret söylemini engellemek için okur yorumlarını filtreleme süreçlerini şöyle anlatmıştır:

“Okur yorumları artık web sitemizden kaldırıldı. Bizde haberler yönetim kararıyla yorumlara kapatıldı. Çünkü okur yorumlarını denetlemek hiç kolay değil. Gözden kaçan yorumlar gazeteler için çok ciddi sıkıntılara yol açabiliyor. Bir tane haberin altına 5 bin 
tane yorum geliyor. Çok hızlı okurken, gözden etik dışı bir cümle kaçabiliyor. Nefret söylemi ya da küfür gibi ifadeler sıkıntılara yol açıyor."

\section{Sonuç}

Dijitalleşmenin gazeteciliğe etkilerini ve ortaya çıkardığı yeni etik sorunları ele alan çalışma, bu etkinin boyutlarını ve şiddetini bizzat gazetecilikte dijitalleşme pratiğinin ilk elden deneyimleyicisi olan internet editörlerinin görüşlerine başvurarak ortaya koymayı hedeflemiștir. Böylece konu hakkında en fazla gözlem ve deneyime sahip olduğu düşünülen özel bir kitlenin görüşleri doğrultusunda etkinin boyutları ve şiddetini belirlemek amaçlanmıştır. Bu kapsamda Hürriyet, Sabah ve Milliyet gazetelerinin internet editörleri çalışmanın örneklemini oluşturmuştur.

Çalışmadan elde edilen sonuçlara göre gazeteciler, "hızlı veri aktarımına olanak tanıması", "haberleri yazılı, işitsel ve görsel olarak sunmaya yarayan multimedya fonksiyonu", "dağıtımı bir sorun olmaktan çıkarması", "haber üretim maliyetlerini düşürmesi”, "kullanılan araç/gereçlerin küçülmesi ve hafiflemesinin haber üretimini pratikleştirmesi”, "haberlerin gelişmeler meydana geldikçe sürekli güncellenebilmesi ve hataların kısa zamanda düzeltilebilmesi", "hiperlinklerin kullanımı ile haberin ardalanının sunulabilmesi" ve "yer ve zaman sınırının ortadan kalkması" gibi özellikleri dijitalleşmenin gazetecilik pratiklerine olumlu etkileri arasında saymıștır.

Gazetecilere göre dijitalleşme, gazetecinin haber kaynağı ile olan ilişkisini ve habere ulaşma yollarını da etkilemiștir. Gazeteciler dijitalleşme ile birlikte "tık odaklı bir habercilik pratiğinin yaygınlaştığını", "sosyal medyanın ve internetin kendisinin de bir haber kaynağına dönüştüğünü", "haber kaynağı ile sanal görüşme yapmanın mümkün hale geldiğini”, "internetin veri gazeteciliğini olanaklı kıldığını" ve bunların sonucunda da "masabașı haberciliğin yaygınlaștığını" belirtmiștir.

Gazetecilere göre bu gelişmelerin bir kısmı ise internet gazeteciliğinde yeni etik sorunları da beraberinde getirmiştir. Görüşülen gazetecilere göre habercilik açısından dijitalleşmenin yarattığı en önemli ilk üç etik sorun "hataların büyük bir hızla yayılarak" birilerine zarar verebilme riski, "zaman ve rekabet baskısı" yüzünden hata yapma oranının artması ve habercilik için harcanan emeğin kolayca çalınabilmesiyle ortaya çıkan "telif" sorunudur. Yine gazeteciler, pek çok haber sitesinde "editoryal yeterliliği bulunmayan kișilerin istihdam edilmesi" ve "haber faktörleri ile gazetecilik ilkelerinin yeterince denetlenmemesi/denetlenememesi"ni de görüşmelerde dile getirmiștir.

Gazetecilere göre gazetecilikte dijitalleşmenin okur açısından ortaya çıkardığı etik sorunlardan en önemlileri ise "yanıltıcı başlıklandırma ve içerik (tık tuzağı)", "gerçekdışı haberlerin hızla yayılması" ve "internette gazetecinin ve haberin güvenilirliğinin azalması" olarak belirtilmiştir. Gazetecilere göre diğer etik sorunlar ise sırasıyla "okurun bilgi çöplügü ile karşı karşıya kalması", "okurun tüketici olarak görülmesi”, "haber/reklam ayrımı arasındaki bulanıklık", "kişilik haklarının ihlali", "sanal galeriler" "konuyla ilgisiz fotoğraf ve link kullanımı" ve "siber zorbalık/nefret söylemidir." Gazeteciler "veri madenciliği" ve "dijital gözetim"i de etik birer sorun olarak görmekle birlikte internet gazeteciliğinde daha az rastlandığı konusunda görüş bildirmişlerdir.

Sonuç olarak, görüşülen gazetecilere göre dijitalleşmenin gazetecilikte haber üretim sürecine olumlu ve olumsuz etkileri olmuştur. Diğer taraftan gazeteciler, haberler 
dolayımıyla hem habercilik hem de okur açısından geleneksel basında daha önce karşılaşılmayan yeni etik sorunların ortaya çıktığını da düşünmektedir. Gazetecilerin özellikle yanıltıcı başlık ve içerik, tık tuzakları, gazeteciler üzerindeki zaman baskısının hataların ortaya çıkmasına yol açması, yapılan hataların yol açabileceği zararlar gibi konulardan rahatsız oldukları ve bu tür uygulamaların internette gazeteciliğin güvenirliğine zarar verdiği görüşünde birleştikleri görülmüştür.

$\mathrm{Bu}$ çalışma, gazetecilikte dijitalleşmenin yarattığı değişim ve dönüşümü medya çalışanları gözüyle ortaya koymayı amaçlamıştır. Araştırma ile dijitalleşmenin habercilik ve gazetecilik mesleği açısından etkilerini ve internet gazeteciliğinde karşılaşılan etik sorunlara ilişkin gazetecilerin görüşlerini ortaya koymak hedeflenmiştir. Çalışma doğrultusunda gazetecilerin birinci elden verdiği bilgilerin, konuyla ilgili yeni araştırmalar için yol gösterici olabileceği düşünülmektedir. Bundan sonraki çalışmalarda gazeteciler, gazetecilik meslek örgütleri ve akademisyenlerle görüşülerek, dijitalleşmenin gazetecilikte haber üretim sürecine, gazetecilerin çalışma şartlarına ilişkin olumsuz etkileri ve haberler dolayımıyla ortaya çıkan etik sorunlara yönelik çözüm önerileri tespit edilebilir.

\section{Notlar}

${ }^{1}$ Doğan Grubu, Hürriyet Gazetesi'ni grubun diğer medya organları ile birlikte 22.03.2018 tarihinde Demirören Grubu'na satmak için ön protokol imzalamış, 17.05.2018 tarihinde yapılan açıklama ile ise satış ve devir işlemlerinin tamamlandığı duyurulmuştur. Kaynak: http://www.hurriyet.com.tr/ekonomi/dogan-medyanin-demirorene-satis-vedevri-tamamlandi-40839268 Erişim: 16.11.2018

${ }^{2}$ Bu konudaki örneklerden biri Hürriyet gazetesinde, 13 Kasım 2015 tarihinde yaşanmıştır. Hürriyet’in web sitesinde yayımlanan ‘13'üncü Cuma uğursuzluğu' başlıklı bir haberde Leonardo da Vinci'nin dünyaca ünlü 'Son akşam yemeği' tablosu kullanıımıştır. Ancak Hürriyet’te yayımlanan haberde yer alan fotoğrafın, orijinal tabloya Cumhurbaşkanı Recep Tayyip Erdoğan'ın fotoğrafının monte edildiği sahte bir versiyonu olduğu sonradan fark edilmiştir. Fotoğraf kısa sürede yayından kaldırılsa da, bu dikkatsizlik nedeniyle hatada sorumluluğu tespit edilen editör ile metnin hazırlandığı dijital yan yayınlar bölümünün başında bulunan içerik müdürünün görevine son verilmiştir. http://www. diken.com.tr/13uncu-cuma-kurbanlari-hurriyet-erdogandan-ozur-dileyip-iki-calisanini-kovdu/ (Erişim: 04.04.2018).

\section{Kaynakça}

Bayraktutan, G. (2012). Yeni Medyanın Etik Sorunları Üzerine Bir Değerlendirme. Deniz Yengin (Ed). Yeni Medya ve.., İstanbul: Anahtar Kitaplar.

Bersey, A., Chadwick, R. (1998). Medya ve Gazetecilikte Etik Sorunlar. A. Bersey \& R. Chadwick (Der). Nurçay Türkoğlu (Çev). İstanbul: Ayrıntı Yayınları.

Bersey, A., Chadwick, R. (1998). Medyada Etik ve Siyaset: Kalite Arayışı,. Bersey, A., R. Chadwick (Der). Nurçay Türkoğlu(Çev). Medya ve Gazetecilikte Etik Sorunlar. İstanbul: Ayrıntı Yayınları.

Binark, M. Yeni Medya, Gençlik ve Gündelik Yaşam, https://yenimedya.wordpress. com/calismalar/, Erişim Tarihi: 02.04.2018.

Binark, M., Bayraktutan, G. (2013). Ayın Karanlık Yüzü: Yeni Medya ve Etik, İstanbul: Kalkedon Yayınları.

Chen, Y., Conroy, N. J., Rubin, V. L. Misleading Online Content: Recognizing Clickbait as False News (Elektronik Sürüm). 17th ACM International Conference on Multimodal Interaction, Washington.

Deuze, M. (2003). The web and its journalisms: considering the consequences of different types of newsmedia online (Elektronik Sürüm). New media \& Society, 5(2), 203-230. 
Diaz, J. C., Segado - Boj, F. (2015). Journalism Ethics in a Digital Environment: How Journalistic Codes of Ethics Have Beeen Adapted to the Internet an ICTs in Countries Around The World, Telematic an Informatics, 32, 735-744.

Dönmez, İ. H. (2010). "İnternet Haberciliğinde Tıklanma Kaygısı ve Kapan Manşetler.” Akdeniz Üniversitesi İletişim Fakültesi Dergisi,14, 105-128.

Erdoğan, İ. (2006). Medya ve Etik: Eleştirel Bir Giriş. İletişim Kuram ve Araştırma Dergisi, 23, 1-26.

Evers, H. (2010a). Medya Etiği. Çaplı, B., Tuncel, H. (Ed). Televizyon Haberciliğinde Etik (s. 45-61), Ankara: Fersa Matbaacilık.

Evers, H. (2). (2010b). İnternet Haberciliği: Yeni Etik Sorunlar mı?. Çaplı, B., Tuncel, H. (Ed). Televizyon Haberciliğinde Etik (s. 322-328).

Geray, H., Aydoğan, A. (2010). Yeni İletişim Teknolojileri ve Etik. Çaplı, B., Tuncel, H. (Ed). Televizyon Haberciliğinde Etik (s. 310-317). Ankara: Fersa Matbaacılık.

http://basinkonseyi.org.tr/basin-meslek-ilkeleri/, Erişim: 20.02.2016

https://www.tgc.org.tr/bildirgeler/turkiye-gazetecilik-hak-ve-sorumlulukbildirgesi.html, Erişim: 06.04.2018

Işık, U. ve Koz, K. A. (2014). “Çöp Yığınlarında Haber Aramak: İnternet Gazeteciliği Üzerine Bir Çalışma." Humanities Science 9 (2): 27-43. dx.doi.org/10.12739/ NWSA.2014.9.2.4C0178.

İrvan, S. (2005). Medya ve Etik. Medya, Etikve Hukuk. (s. 61-109). Sevda Alankuş(Der.), İstanbul: Bia Ips İletişim Vakfı Yayınları.

Kalan, Ö. (2016). Yeni Medyada Reklam ve Etik Sorunlar, Atatürk İletişim Dergisi, 10, $71-89$.

Kuçuradi, I. (1999). Philosophical Ethics and Professional Ethics, Introduction Ethics of the Professions: Medicine (ed. Ioanna Kucuradi), Business, Media, Law (Elektronik Sürüm). New York: Springer.

Nigel G., E. Harris. (1998). Gazeteciler için davranış kodları. A. Bersey \& R. Chadwick (Der). Nurçay Türkoğlu (Çev). İstanbul: Ayrıntı Yayınları.

Özel, E. K. (2016). Okur Yorumlarında Etik Sorunlar: Gazetecilerin Konuya Yaklaşımı, Uluslararası Sosyal Araştırmalar Dergisi, 9 (43).

Özyal, B. (2016). Tık Odaklı Habercilik: Tık Odaklı Haberciliğin Türk Dijital Gazetelerindeki Kullanım Biçimleri, Global Media Journal TR Edition, 6 (12).

Pavlik, J. V. (1). (2001). Journalism and New Media (Elektronik Sürüm). New York: Columbia University Press.

Pavlik, J. V. (2). (2008). Media in the Digital Age (Elektronik Sürüm). New York: Columbia University Press.

Taş, O. (2010). Medya Etiğinin Tarihsel Temelleri ve Gelişimi. Çaplı, B., Tuncel, H. (Ed). Televizyon Haberciliğinde Etik (s. 3-27). 
